SBP Research Bulletin

Volume 7, Number 1, 2011

\title{
Household Leverage and the Recession of 2007 to 2009
}

\begin{abstract}
Atif Mian*
Amir Sufi ${ }^{* *}$

Abstract: We show that household leverage as of 2006 is a powerful statistical predictor of the severity of the 2007 to 2009 recession across U.S. counties. Counties in the U.S. that experienced a large increase in household leverage from 2002 to 2006 showed a sharp relative decline in durable consumption starting in the third quarter of 2006 - a full year before the official beginning of the recession in the fourth quarter of 2007. Similarly, counties with the highest reliance on credit card borrowing reduced durable consumption by significantly more following the financial crisis of the fall of 2008. Overall, our statistical model shows that household leverage growth and dependence on credit card borrowing as of 2006 explain a large fraction of the overall consumer default, house price, unemployment, residential investment, and durable consumption patterns during the recession. Our findings suggest that a focus on household finance may help elucidate the sources of macroeconomic fluctuations.
\end{abstract}

JEL Classification: D14, E32

Keywords: household leverage, credit crisis, recession, consumer default

\section{Introduction}

Understanding the sources of deep recessions is the holy grail of macroeconomics. The most recent recession has produced a sharp increase in unemployment and a large decline in GDP (Figure 1, top two panels). What factors explain the current

\footnotetext{
* Associated with University of California, Berkeley, CERP and NBER; atif@haas.berkeley.edu; and University of Chicago Booth School of Business and NBER; amir.sufi@chicagobooth.edu respectively. Authors thank Pierre-Olivier Gourinchas, Ayhan Kose, Kevin Lansing, two anonymous referees, and seminar participants at the University of Chicago (Booth), Duke University (Fuqua), Purdue University (Krannert), Harvard Business School, Princeton University, Wharton, NYU (Stern), and the Annual Research Conference at the IMF for comments. Timothy Dore provided superb research assistance. They thank National Science Foundation, the Initiative on Global Markets at the University of Chicago Booth School of Business, the Center for Research in Security Prices, and the FMC Corporation for funding. The results or views expressed in this study are those of the authors and do not reflect those of the providers of the data used in this analysis.
} 
economic downturn? This paper focuses on the role of household leverage. We show that household leverage measured as of 2006 is an early and powerful statistical predictor of cross-sectional county-level variation in household default, house price, unemployment, residential investment, and durable consumption from 2007 to 2009. Any realistic macroeconomic theory of the 2007 recession must be consistent with the time-series and cross-sectional patterns documented in this paper.

The aggregate U.S. evidence highlights the potential importance of household leverage. The bottom panel of Figure 1 shows the unprecedented increase in the U.S. household debt to income ratio during the years prior to the recession. In 2007, the household debt to GDP ratio reached its highest level since the onset of the Great Depression. The initial indicators of economic difficulty, namely a rise in household defaults and a decline in house prices, were also related to household leverage. These trends began as early as the second quarter of 2006, a full five quarters before the initial increase in the unemployment rate. The components of GDP that initially declined in 2007 and early 2008 were fixed residential investment and durable consumption - two components that most heavily rely on the willingness of households to obtain additional debt financing. While aggregate patterns are suggestive, it is difficult to reach definitive conclusions on the link between household leverage and the economy based on aggregate data alone. For example, it is possible that the decline in house prices and the increase in defaults in 2006 reflected an anticipation of future unemployment. Or perhaps the household-leverage component of the recession, while occurring early in the downturn, is far less important than the credit crisis of September and October of 2008. More generally, the linkages across the economy make it difficult to conclude based on aggregate evidence alone what factors contributed the most to the severe recession of 2007 to 2009.

Our focus on cross-sectional variation across U.S. counties in the severity of the recession helps to overcome some of the difficulties associated with aggregate data. There is a large degree of such variation across counties. For example, Saint Lucie County in Florida experienced an increase in the unemployment rate of 6.6 percent from 2006 to 2008. In contrast, Harris County in Texas, where Houston is located, had a rise of only 1.2 percent in the unemployment rate. Our empirical methodology examines patterns across U.S. counties to explore why some counties have experienced a much more severe recession than others.

We sort counties according to the increase in the household debt to income ratio from 2002 to 2006, and we refer to counties with large (small) increases in leverage during this period as high (low) leverage growth counties. We find that 
the recession both began earlier and became more severe in high leverage growth counties relative to low leverage growth counties. The top 10 percent leverage growth counties experienced an increase in the household default rate of 12 percentage points and a decline in house prices of 40 percent from the second quarter of 2006 through the second quarter of 2009. In contrast, the bottom 10 percent leverage growth counties experienced a modest increase of 3 percentage points in the default rate and a 10 percent increase in house prices. Auto sales and new housing building permits reveal a similar pattern. By the third quarter of 2008, auto sales in the top 10 percent leverage growth counties declined by almost 40 percent relative to 2005. In contrast, auto sales in the bottom 10 percent leverage growth counties were actually up almost 20 percent. From 2005 to 2008, new housing building permits declined by almost 150 percent in high leverage growth counties while declining only 50 percent in low leverage growth counties. To the best of our knowledge, we are the first to examine durable consumption and residential investment patterns across U.S. counties during a recession, and the first to show the link between household leverage and the decline in these variables.

The final measure of economic activity we examine is the unemployment rate. Similar to the pattern in auto sales, the unemployment rate increased in high leverage growth counties much earlier than low leverage counties. From the fourth quarter of 2005 to the third quarter of 2008, the unemployment rate climbed 2.5 percentage points in the top 10 percent leverage growth counties; in contrast, the bottom 10 percent leverage growth counties experienced no change in unemployment.

The evidence suggests that both the timing and the severity of the recession were related to the increase in household leverage from 2002 to 2006. Counties that experienced a large increase in their debt to income ratio before the onset of the downturn were precisely the counties that experienced the sharpest decline in durable consumption and the largest increase in unemployment. We also show that the correlation between leverage growth and the severity of the recession is robust to county-level control variables for demographics, cyclicality, and industrial composition.

While counties with low leverage largely escaped the recession up to the third quarter of 2008, auto sales dropped and unemployment skyrocketed in both high and low leverage growth counties from the fourth quarter of 2008 through the second quarter of 2009. In other words, the growth in household leverage from 2002 to 2006 is not correlated with the severity of the downturn across U.S. counties during the last three quarters of the recession. In the last section of our 
analysis, we examine what factors other than household leverage growth from 2002 to 2006 are correlated with acceleration of the recession from the fourth quarter of 2008 to the second quarter of 2009. We find that the severity of the downturn in these three quarters is correlated with an alternative measure of household leverage: household exposure to short term credit, as measured by the credit card utilization rate as of 2006. Counties with high credit card utilization rate experienced a sharper drop in auto sales from the fourth quarter of 2008 through the second quarter of 2009. This coincides with a sharp reduction in credit card availability that occurs simultaneously with the financial crisis in September and October of 2008.

Our findings suggest that households faced a one-two punch during the recession. From the fourth quarter of 2006 to the third quarter of 2008, an over-levered household sector facing mounting defaults and falling house prices pulled back on durable consumption and experienced higher unemployment rates. From the fourth quarter of 2008 onwards, credit-card dependent consumers reduced consumption as credit card availability was cut dramatically.

We assess the statistical magnitude of the household leverage effect by using our estimated regression coefficients to predict the severity of the recession across the household leverage distribution. Using this methodology, we find that the growth in household leverage from 2002 to 2006 and household dependence on credit card borrowing as of 2006 are quantitatively sufficient to statistically explain the entire rise in household defaults, the drop in house prices, and the drop in auto sales. Our factors also explain about a fifth of the overall rise in unemployment. The reduced explanatory power for unemployment is a natural outcome of the fact that goods consumed in one location are often produced in different locations, therefore naturally lowering the correlation between local consumption and production shocks. ${ }^{1}$

Overall, our findings suggest that household balance sheets are a crucial component of explaining macroeconomic fluctuations. The idea that household debt instigates and exacerbates economic downturns goes back to Fisher (1933), and is reiterated in subsequent research by Mishkin (1978), King (1994), Leamer (2007, 2009), and Glick and Lansing (2009, 2010). Leamer (2007, 2009) points out that eight of the past ten recessions were preceded by substantial problems in housing and consumer durables. Our paper provides the first micro-level cross-

\footnotetext{
${ }^{1}$ For example, reduced recreational vehicle (RV) sales in Los Angeles County due to household leverage may lead to a sharp increase in unemployment in Elkhart County, Indiana, even though Elkhart County has low household leverage.
} 
sectional evidence based on the 2007 to 2009 recession of the link between household balance sheets and an economic downturn. ${ }^{2}$

Our empirical findings should also serve as a useful metric for guiding theoretical work on understanding business cycle fluctuations. Standard DSGE models of business cycles often ignore the role of financial markets (see Tovar 2008). While this has changed more recently (see e.g. Christiano et al., 2007), the emphasis has been on firm and bank level, not household level. ${ }^{3}$

Our work on the other hand points to the potential importance of household balance sheets in explaining macroeconomic fluctuations. While more research is needed to determine whether household leverage was a catalyst of the recession or an amplification of other variables, such as technology or monetary shocks, any explanation of the recession of 2007 to 2009 must be consistent with the strong correlation between household leverage and subsequent economic outcomes in the cross-section of U.S. counties.

Our results are closely related to the persistent business cycle fact that residential investment and durable consumption are strong leading indicators of business cycles. This finding deserves closer scrutiny by theoretical work. While many macro models predict that investment is a leading indicator of business cycles, most have difficulty in explaining why household investment should lead business investment over the business cycle. This difficultly is recognized by Fisher (2001) as a "potent challenge to real business cycle theory".

The rest of the study proceeds as follows. In the next section, we provide aggregate evidence on the importance of household leverage. In section 3 , we describe the county-level data and provide summary statistics. In section 4 , we focus on the relation between leverage growth from 2002 to 2006 and economic outcomes from 2006 to 2009. Section 5 explores alternative hypotheses and shows how credit card-reliant borrowers responded to the financial crisis of the fall of 2008. Section 6 presents our magnitude estimation, and section 7 concludes.

\section{Household leverage and the real economy}

\section{A. The origins of household leverage}

What factors led to the dramatic expansion in household leverage from 2001 to 2007? This is the central question of two of our previous studies. In Mian and Sufi

\footnotetext{
${ }^{2}$ Glick and Lansing (2009) find similar results in the cross-section of western countries.

${ }^{3}$ Iacovello (2005) is an important exception.
} 
(2009a), we argue that the advent of subprime mortgage securitization represented a credit supply shock that provided new home purchase financing for a segment of the population that traditionally was unable to obtain mortgages. We are agnostic on the source of the credit supply shock - it is likely that government programs (Leonnig, 2008), moral hazard on behalf of originators and servicers of securitization pools (Keys et al., 2010), and the enormous capital inflows into the United States (Obstfeld and Rogoff, 2009) all played some role. We present evidence that the credit supply shock led to an increase in house prices, which led to an important collateral feedback effect: once collateral values increased, lenders were willing to lend even more to households (Kiyotaki and Moore, 1997).

In Mian and Sufi (2009b), we focus on existing homeowners who owned their homes before the credit supply shock. We find that existing homeowners responded to house price growth by borrowing heavily against the increase in the value of their home equity. We find that homeowners borrowed 25 to 30 cents on every dollar of home value appreciation, and that this home equity-based borrowing channel accounts for a substantial fraction of the increase in homeowner debt from 2002 to 2006. To summarize, two related factors are responsible for the rise in household leverage between 2001 and 2007. First, an expansion in the supply of credit (as opposed to a productivity driven demand side shock) pulled new buyers into the housing market, pushing house prices up in the process. Second, the increase in house prices and low interest rates enticed existing homeowners to extract cash from their home equity.

\section{B. Household leverage and the real economy}

Following the historic rise in household leverage, the top panel in Figure 2 shows that beginning in the second quarter of 2006, default rates began to rise and house prices began to fall. As early as the second quarter of 2007 - two months before the beginning of the current recession - default rates were already above the levels they had reached in the 2001 recession. By the second quarter of 2009, the default rate neared 10 percent, which is twice as high as any point since 1991. Total delinquent debt as of the second quarter of 2009 was $\$ 1.7$ trillion. $^{4}$

The process of household de-leveraging began in the second quarter of 2008 (lower panel). Households cut back on consumption as the personal savings rate reached 5.2 percent in the second quarter of 2009 - the highest it has been in over

\footnotetext{
${ }^{4}$ Throughout, the household default rate refers to the default rate on all household debt, including housing and non-housing related. In our sample as of 2006, housing-related debt (mortgages and home equity lines) is on average $80 \%$ of total debt across U.S. counties. Further, a regression of housing-related default rates on total default rates yields $\mathrm{R}^{2}$ of 0.98 ; i.e., most of the variation across counties in household default rates is driven by variation in housing-related default rates.
} 
a decade. As early as the fourth quarter of 2007, debt growth began to moderate. From the fourth quarter of 2008 to the second quarter of 2009, total household debt declined for three straight quarters - something that had not previously occurred in the past 60 years for which quarterly data are available.

Why did mortgage defaults begin to rise and house prices begin to fall in the middle of 2006? This question is beyond the scope of our analysis, but we offer three potential reasons. First, rising interest rates likely played a role in reducing house prices by lowering the relative advantage of homeownership (Mayer and Hubbard, 2008). Second, lending standards on mortgages deteriorated to such a degree that mortgages originated in 2006 experienced shockingly high default rates almost immediately after origination (Demyanyk and Van Hemert, 2008). Third, even small increases in default rates may have shut down securitization markets, leading to an amplification effect on default rates as households were unable to refinance. One thing is certain: the rise in mortgage defaults and collapse in house prices preceded the aggregate rise in the unemployment rate. Figure 3 shows that the increase in default rates (top panel) and decrease in house prices (bottom panel) started five quarters before any increase in the aggregate unemployment rate.

Figure 4 shows the decline in real activity. Starting in the first quarter of 2006, residential fixed investment growth began to plummet. By the fourth quarter of 2007, residential fixed investment had declined almost 50 percent from its 2005 level. In contrast, non-residential fixed investment showed robust growth until the third quarter of 2008. The middle panel of Figure 4 shows a similar pattern for durable consumption, which leveled off in 2007 before experiencing sharp declines through 2008. Non-durable and service consumption remained strong until the end of 2008.

The bottom panel of Figure 4 shows monthly retail sales; as it shows, the drop in durable consumption (motor vehicles, and furniture and appliances) began very early in the recession. The drop in auto sales was particularly large - from the fourth quarter of 2007 to the fourth quarter of 2008, auto sales dropped by 30 percent. The drop in non-durable consumption both began later and was far less severe.

Figure 4 shows that the initial part of the economic downturn was driven by declines in durable consumption and residential investment. This is common in post World War II recessions (Leamer, 2007, 2009). The early drops in these two GDP components during the 2007 to 2009 recession occurred simultaneously with an extremely large increase in household defaults. Given the importance of credit 
in the purchase of durable goods and housing, there is a suggestive link between deterioration of household balance sheets and the early decline in durable and housing consumption.

While the aggregate patterns are suggestive of a link between household leverage and the recession, we urge caution in the interpretation of the evidence. A main disadvantage of aggregate data is the inability to distinguish between competing hypotheses that imply similar time series patterns in aggregate activity. For example, residential investment and durable consumption may have declined given expectations of future unemployment increases. In the next section, we begin our analysis of the cross-section of U.S. counties to provide further evidence on the link between household leverage and the 2007 to 2009 recession.

\section{County-level data and summary statistics}

We build the county-level data set from a variety of sources. Information on household debt, default rates, and credit scores comes from Equifax zip code level aggregates. Data on house prices come from the FHFA MSA level house price indices, which are subsequently matched to counties. Zip code level income information is available from the IRS, and zip code level demographics are from the 2000 Decennial Census. More information on these data sets is available in the appendix of Mian and Sufi (2009a). The zip code level data in Equifax are aggregated to the county level by weighting each zip code by the fraction of all consumers with a credit report in the county living in the zip code. The IRS and Census zip code level data are aggregated to the county level using the number of households in the 2000 census as weights.

There are four new county-level data sets that we do not employ in our previous studies. The first includes auto sales data from R.L. Polk. Polk is an automotive intelligence company that provides detailed auto sales data to a variety of customers. The data are collected by examining new vehicle registrations at the county level. The data are available from 2004 to 2009 at a quarterly frequency, and they cover every county in the United States. ${ }^{5}$ County-level unemployment data are from the Bureau of Labor Statistics, who provides quarterly unemployment rate data for all U.S. counties. We use county business patterns data from the Census Bureau to construct industry composition of employment for each county. The business patterns data records payroll and employment data by

\footnotetext{
${ }^{5}$ These data are available for purchase from R.L. Polk. For pricing information and purchase, please contact Robert Sacka at robert_sacka@polk.com, and mention the county-level quarterly auto sales data used in this study.
} 
industry for each county and is available with a three year lag. New housing permits also come from the Census Bureau. ${ }^{6}$

While there are 3,138 counties in the U.S., we restrict our attention to the top 450 counties by population. These are counties with at least 50,000 resident households, which cover 70 percent of the U.S. population and 82 percent of the aggregate debt outstanding as of the end of 2005. Since our focus is on countylevel analysis in this paper, we drop very small counties that add significant measurement error. All of our results are unchanged if we include small counties, but give them their appropriate statistical weight by weighing with population. ${ }^{7}$

Every state and the District of Columbia are represented by the counties in our sample, with the exception of Wyoming. To get a sense of the counties included, we list in the Appendix Table every fifth county in our final sample, where the counties are sorted inversely according to the change in the debt to income ratio from 2002 to 2006.

Table 1 presents summary statistics for the final sample of 450 counties. The key variable of interest in our study is the increase in the debt to income ratio across counties from 2002 to 2006. The average debt to income increase across counties from 2002 to 2006 was 0.8 . In 2001, the average debt to income ratio was 2.2 with a standard deviation of 0.5. It implies that the increase from 2002 to 2006 was more than one full standard deviation of the 2001 level. The average increase in the default rates of counties from 2006-Q4 to the 2009-Q2 was 0.043, which is almost three times as large as one standard deviation of the 2006 level. House prices collapsed from 2006 to 2009, with the average decline across counties in our sample of 14 percent. House price data are only available for 123 counties; this reflects the limits of the coverage of MSAs by FHFA.

Table 1 also shows that auto sales plummeted by an average of 32 percent from the fourth quarter of 2006 to the second quarter of 2009. Over the same time period, the unemployment rate increased by an average of 5.4 percentage points, which is more than 4 times a standard deviation of the 2006 level. Table 1 also includes information on Census demographics and county business patterns across the 450 counties in our sample.

\footnotetext{
${ }^{6}$ County-level census data are available at: www2.census.gov/prod2/statcomp/usac/excel/

${ }^{7}$ The results using the full sample and equally weighting counties are qualitatively similar but are smaller in magnitude. This is consistent with higher measurement error in very small counties. Consistent with this explanation, the $\mathrm{R}^{2}$ of equally weighted regressions using the full sample are only between $1 / 3$ and $1 / 2$ as large as the $R^{2}$ of population weighted regressions using the full sample.
} 


\title{
4. Household leverage and the real economy: County-level analysis
}

In this section, we examine how household leverage growth in a given county from 2002 to 2006 is correlated with the timing and severity of the recession in the county. As we show, counties with the largest increases in household leverage experienced the earliest and most severe downturns in economic activity.

\begin{abstract}
A. Methodology
There are five county-level economic outcomes we evaluate: mortgage default rates, house price growth, auto sales, new housing building permits, and unemployment. The goal of our methodology is to see how the increase in leverage from 2002 to 2006 in a given county is correlated with these county-level outcomes during the recession. We first split the sample into high and low leverage growth counties. High leverage growth counties are counties in the top 10 percent of the distribution of the increase in the debt to income ratio from 2002 to 2006. For example, Merced County in California experienced an increase in its aggregate debt to income of 2.3 from 2002 to 2006. Low leverage growth counties are counties in the bottom 10 percent of the same distribution. For example, Tarrant County in Texas experienced almost no increase in its debt to income ratio from 2002 to 2006. Once we split the sample into high and low leverage growth counties, we present figures that plot each economic outcome from the fourth quarter of 2004 to the end of the sample. This technique shows both the timing and severity of the downturn in high versus low leverage growth counties.
\end{abstract}

Our second approach is to present figures that contain the county-level scatter plot of the change in each economic outcome during the recession against the rise in leverage that preceded the recession. For example, for each county, we plot the increase in the unemployment rate from the fourth quarter of 2006 to second quarter of 2009 against the rise in household leverage from the fourth quarter of 2002 to the fourth quarter of 2006.

Third, for each outcome, we present a series of first difference regressions with county level control variables. The following equation represents the general form of the first difference specifications:

$$
\text { Economicoutcome } 06 q 4_{-} 09 q 2_{i}=\beta * \text { LeverageGrowth02q } 4_{-} 06 q 4_{i}+\Gamma * \text { ControlVariables } s_{i}+\varepsilon_{i}
$$

where EconomicOutcome06q4_09q2 represents the change in the outcome (house prices, default rates, unemployment, and auto sales) for county $i$ from the fourth quarter of 2006 to the second quarter of 2009, LeverageGrowth02q4_06q4 
represents the increase in the debt to income ratio in county $i$ from the fourth quarter of 2002 to the fourth quarter of 2006, and ControlVariables is a set of cyclicality, demographic, and industrial composition measures for county $i$. In estimating specification (1), we weight by the total number of households in the county as of 2000 to account for the fact that variables measured over smaller populations have larger variance. We also report unweighted regression results in all our tables. Standard errors in all specifications are clustered at the state level.

In the regression specifications, we choose to measure household leverage growth up to 2006 because it reflects when the household leverage cycle shifted from expansion to contraction. As Figure 2 shows, the decline in house prices and the increase in household defaults began in 2006. Although the recession did not formally begin until the fourth quarter of 2007 according to the NBER, we choose to measure economic outcomes from the fourth quarter of 2006 because default rates increased rapidly and house priced declined sharply in 2007. All results are qualitatively and quantitatively similar if we measure outcomes from the fourth quarter of 2007. Further, as mentioned above, we plot all outcomes for high and low leverage growth counties from 2004 onwards in order to show the exact timing of economic outcomes.

In most of our empirical tests, we take the variation across counties in leverage growth from 2002 to 2006 as given. In other words, we do not attempt to discern why some counties experienced sharper increases in household leverage than others. This issue is addressed in our previous studies. In both Mian and Sufi (2009a) and Mian and Sufi (2009b), we show that an aggregate credit supply shock beginning in 2002 shifted the demand for housing across the country. The degree to which house prices increased in respond to this housing demand shock depended crucially on the slope of the housing supply curve. In counties with relatively elastic housing supply, house prices were relatively steady as homebuilders responded to the demand shock by constructing more homes. In counties with relatively inelastic housing supply, house prices increased given the difficulty in constructing more homes to meet new demand.

As a corollary, as counties with inelastic housing supply experienced sharper increases in house prices, existing homeowners aggressively borrowed against the value of their homes (Mian and Sufi, 2009b) and new homeowners were forced to take out larger mortgages to buy more expensive homes (Mian and Sufi, 2009a). The primary measure of housing supply elasticity we use in the previous studies comes from Saiz (2008), who constructs his measure based on geographical and topographical constraints on house construction. 
The impact of housing supply elasticity on leverage growth is quite strong: a county level regression of the increase in the debt to income ratio from 2002 to 2006 on the Saiz (2008) measure of housing supply inelasticity shows a strongly positive correlation with an $\mathrm{R}^{2}$ of almost 0.2 . This motivates our final test of the relation between leverage growth and economic outcomes, which is the following instrumental variables specification:

$$
\begin{aligned}
& \text { EconomicOutcome } 06 q 4_{-} 09 q 2_{i}=\beta * \text { LeverageGrowth } 02 q 4_{-} 06 q 4_{i}+\Gamma * \text { ControlVariables } s_{i}+\varepsilon_{i} \\
& \text { LeverageGrowth02 } q 4_{-} 06 q 4_{i}=\gamma * \text { HousingSupplyinelasticity } y_{i}+\Theta * \text { ControlVariables }_{i}+u_{i}
\end{aligned}
$$

Where equation (3) represents the first stage in which leverage growth is regressed on the Saiz (2008) measure of housing supply inelasticity. The second stage is identified using the predicted values of LeverageGrowth02q4_06q4 for each county. We examine the exclusion restriction in great detail in our previous work, and we come to the conclusion that differential patterns in economic outcomes in the IV specification above come through house price growth and its effect on household leverage.

\section{B. Default Rates and House Prices}

Figure 5A shows differential patterns for default rates and house prices for high versus low leverage growth counties. Counties that experienced the largest increase in their debt to income ratio from 2002 to 2006 saw a tremendous rise in household default rates. Beginning in the second quarter of 2006, the household default rate in high leverage growth counties began to skyrocket. By the second quarter of 2009, the default rate increased by 12 percentage points for these counties. In contrast, default rates in low leverage growth counties began to rise later and experienced only a modest increase by 2009. By the end of the sample period, the default rate is almost 10 percentage points higher in high leverage growth counties relative to low leverage growth counties.

The patterns in house price growth are similar. Low leverage growth counties completely avoided the housing downturn. High leverage growth counties were hammered. Starting in 2006, house prices began to plummet in counties that had experienced the largest rise in the debt to income ratio from 2002 to 2006. From 2005 to the second quarter of 2009, house prices dropped a stunning 40 percent in high leverage growth counties.

Figure 5B shows the scatter plots for the change in these two outcome variables from 2006 to 2009 against the increase in household leverage from 2002 to 2006. As they show, the increase in household leverage before the recession in a given 
county strongly predicts the severity of the subsequent default and housing crisis within the same county. The magnitudes are very large: the regression line implies that a one standard deviation increase in leverage growth from 2002 to 2006 leads to a 2/3 standard deviation increase in subsequent default rates and a 2/3 standard deviation decline in subsequent house price growth.

Tables 2 and 3 present the first difference regression analogs to the scatter plots, and they show that the correlations in Figure 5B are robust to the inclusion of control variables. In column 1 of Table 2, the change in the debt to income ratio from 2002 to 2006 is strongly correlated with the increase in default rates from 2006 to 2009. This single variable gives an $\mathrm{R}^{2}$ of 0.45 , which is extremely high for a first-difference cross-section regression. Column 2 presents the coefficient estimate after weighting the observations by the number of households in the county as of 2000 .

In columns 3 and 4, we include a variety of control variables that increase the adjusted $\mathrm{R}^{2}$ substantially. The inclusion of control variables actually increases the size of the coefficient on leverage growth. Column 5 presents the IV estimate where the change in the debt to income ratio is instrumented using the Saiz (2008) measure of housing supply inelasticity. The IV estimate is considerably larger than the OLS estimate, which may be driven by two factors. First, the IV could be correcting for some measurement error in leverage growth. Second, to the extent some of the increase in leverage is driven by real permanent income shocks, it would tend to reduce ex-post differences between high and low leverage growth counties. For example, if high leverage growth were driven by an accurate expectation of higher income growth in future, then leverage growth will not be correlated with high default rates. Since our housing supply elasticity instrument is uncorrelated with such permanent income shock differences (see Mian and Sufi, 2009b for evidence), the IV specification corrects for the endogeneity problem.

The coefficient in column 1 of Table 3 shows the strong negative correlation between leverage growth from 2002 to 2006 and subsequent house price growth. The univariate specification yields an $\mathrm{R}^{2}$ of 0.62 . As before, the inclusion of control variables improves the fit of the regression, but has almost no effect on the relation between leverage growth and house price growth. As with default rates, the IV estimate is larger than the OLS estimate, although the coefficient is not estimated precisely.

C. Auto sales, new housing permits, and unemployment rates

In Figure 6A, we plot the differential patterns in auto sales, new housing building permits, and unemployment rates for high versus low leverage growth counties. 
Counties that experienced the largest increase in their debt to income ratio from 2002 to 2006 saw a severe contraction in auto sales very early in the downturn. By the first quarter of 2008, auto sales dropped 20 percent relative to their 2005 level in high leverage growth counties. In contrast, auto sales were actually up in low leverage growth counties in the first quarter of 2008. In the third quarter of 2008, auto sales dropped in both high and low leverage growth counties, but the drop in high leverage growth counties was much more severe. Interestingly, all counties saw auto sales plummet in the fourth quarter of 2008 and the first quarter of 2009. We return to this latter fact in Section 4.

The upper right panel of Figure 6A plots the differential patterns for new housing permits. High leverage growth counties experienced a much earlier and more severe downturn in new housing permit growth. At the end of 2007, new housing permits declined in counties experiencing a large increase in leverage from 2002 to 2006 by 75 percent. The decline in counties experiencing no increase in leverage from 2002 to 2006 was only 20 percent. The differential only increased from 2007 to 2008.

Perhaps the most important measure of recession severity is the unemployment rate. The bottom panel of Figure 6A shows that the rise in unemployment began much earlier in high versus low leverage growth counties, and the subsequent increase in unemployment was much more severe. As early as the middle of 2007, the unemployment rate had increased more sharply in counties that had experienced the largest increase in their debt to income ratios from 2002 to 2006.

While the unemployment rate is relatively constant in low leverage growth counties through the third quarter of 2008, it increases sharply from the third quarter of 2008 to the second quarter of 2009. This is similar to the pattern in auto sales. In other words, while household leverage is strongly correlated with auto sales and unemployment through the third quarter of 2008, all counties experienced dramatic declines in auto sales and dramatic increases in unemployment during the last part of the recession.

Figure 6B presents the scatter plots of the relation between leverage growth from 2002 to 2006 and the change in auto sales, new housing permits, and unemployment from 2006 to 2009. The plots show a negative correlation between leverage growth and subsequent auto sales growth and leverage growth and subsequent new housing permit growth. The bottom panel shows a positive correlation between leverage growth and subsequent increases in unemployment. The scatter plots show a significant amount of unexplained variation, which we examine in the next section. 
Table 4 presents coefficients from the first difference specification of auto sales growth from the fourth quarter of 2006 to the second quarter of 2009 regressed on leverage growth from 2002 to 2006. The coefficient estimate in column 2 implies that a one standard deviation increase in leverage growth from 2002 to 2006 in a county was associated with a $1 / 2$ standard deviation decrease in auto sales from 2006 to 2009. The inclusion of control variables reduces the magnitude slightly, but the effect is still large and statistically significant. The IV specification in column 5 yields a coefficient estimate that is substantially larger, but less precise.

Table 5 replicates the specifications with the growth in new housing building permits from 2006 to 2008 as the left hand side variable. The coefficient in column 2 implies that a one standard deviation increase in leverage growth from 2002 to 2006 leads to a 1/3 standard deviation decrease in new housing permit growth from 2006 to 2008. The inclusion of control variables does not affect the estimate. The IV specification produces a larger coefficient, but it is measured less precisely.

The results on new housing building permits raise a possible "real estate construction" channel through which household leverage affects real economic activity: the housing boom in high leverage growth counties led to higher employment in real estate construction from 2002 to 2006, and the resulting downturn is a natural response as this sector shrinks. The coefficient estimate in column 6 disputes this hypothesis. The estimate implies that high leverage growth counties experienced less residential housing construction during the housing boom than low leverage growth counties. ${ }^{8}$ This is consistent with our previous research that shows that a credit-induced housing demand shock led to more building in elastic counties (Mian and Sufi, 2009b). In addition, the employment share in construction and real estate as of the end of 2006 is included as a control variable for all economic outcomes, and this control variable does not affect the estimated coefficient on leverage growth in any specification.

Table 6 presents coefficients from the first difference specification of the unemployment rate change from 2006 to 2009 regressed on leverage growth from 2002 to 2006. The coefficient estimate in column 2 implies that a one standard deviation increase in leverage growth from 2002 to 2006 led to a 1/3 standard deviation increase in the unemployment rate during the recession. The inclusion of

\footnotetext{
${ }^{8}$ In an unreported specification, we include census, 2001 economic condition, and 2001 industry share control variables in the column 6 specification and find similar results.
} 
control variables has almost no effect on the magnitude. The IV estimate is even larger than the OLS estimate.

Taken together, these results show that a county's expansion in household leverage from 2002 to 2006 is a powerful statistical predictor of the severity and timing of the economic downturn across U.S. counties. Counties which had experienced the largest increase in their household debt to income ratios were precisely the counties that saw auto sales plummet and unemployment rates increase the most.

\section{The credit crisis and the deepening of the recession}

Household leverage growth from 2002 to 2006 in a county is a strong predictor of the decline in economic activity from the second quarter of 2006 to the third quarter of 2008. Counties with modest increases in debt to income ratios from 2002 to 2006 experience almost no decline in auto sales or increase in unemployment during the early part of the recession. However, as Figure 6A above shows, both high and low leverage growth counties experienced a dramatic decline in auto sales and a dramatic increase in unemployment from the third quarter of 2008 to the second quarter of 2009. In this section, we explore the potential relation between these patterns, the financial crisis, and consumer reliance on credit cards.

\section{A. Credit card utilization rates}

Figure 7 presents evidence on the evolution of credit card and home equity patterns from 2005 through 2009. Availability under credit lines is a useful measure of credit supply given evidence that total available access on a credit line reflects a bank's willingness to lend (see Gross and Souleles, 2002). While the size of a credit line can also reflect consumer demand, the utilization rate (total line less borrowed portion) can offer suggestive evidence of whether supply or demand is driving variation in credit limits. If a decline in credit limits leads to a sharp rise in utilization rates, then the decline in credit limits is more consistent with a shift in credit supply than credit demand. As the top left panel shows, credit card availability increased dramatically during the early part of the recession from the fourth quarter of 2006 to the third quarter of 2008. In other words, while home equity and mortgage credit markets became significantly tighter in the early part of the recession, credit card availability was expanding.

As the middle left panel shows, high leverage growth counties took advantage of these increased limits by borrowing heavily on credit cards during the early part of the recession. Recall that these same counties experienced a sharp increase in 
defaults and unemployment and a sharp decrease in house price growth, residential investment, and auto sales during this same time period. The sharp relative growth in credit card debt from the fourth quarter of 2007 to the third quarter of 2008 for high leverage growth counties was either a last attempt to avoid defaults, or a final draw down on credit cards before inevitable bankruptcy.

As the top left panel shows, the financial crisis in the fall of 2008 led to a sharp reversal in credit card availability. All counties faced a dramatic reduction in credit card availability, which is consistent with a large negative aggregate credit supply shock.

As shown in Figure 6A, both high and low leverage growth counties experienced a sharp decline in auto sales and a sharp increase in unemployment after the third quarter of 2008. How is the large negative consumer credit supply shock shown in Figure 7 related to this pattern? To answer this question, we sort counties based on credit card utilization rates as of the fourth quarter of 2006. Counties with high credit card utilization rates are assumed to be more reliant on short-term unsecured consumer credit. ${ }^{9}$

The top panel of Figure 8 presents the correlation between the credit card utilization rate as of 2006 and the decline in auto sales from the third quarter of 2008 to the second quarter of 2009. There appears to be a negative correlation, although there is a substantial amount of noise. The bottom panel examines the unemployment rate increase from the third quarter of 2008 to the second quarter of 2009. There is a very weak positive correlation between credit card utilization and the subsequent increase in unemployment.

Table 7 presents results relating the credit card utilization rate to changes in economic outcomes during the recession. As column 1 of Table 7 shows, the credit card utilization rate is not related to auto sales growth from the fourth quarter of 2006 to the third quarter of 2008. In other words, our initial measure of household leverage appears to be the dominant force early in the recession. In column 2, we examine auto sales growth for the entire recession; the credit card utilization rate as of 2006 is strongly correlated with the decline in auto sales when we examine the entire recession. The magnitude of the coefficient implies that a one standard deviation increase in credit card utilization rates as of 2006 is associated with a $1 / 3$ standard deviation decrease in auto sales. Household

\footnotetext{
${ }^{9}$ The correlation across counties between the increase in the debt to income ratio from 2002 to 2006 and the credit card utilization rate as of the fourth quarter of 2006 is statistically significantly negatively correlated. As a result, we are able to separately test the household leverage growth channel from the credit card reliant-consumer channel.
} 
leverage growth from 2002 to 2006 continues to be correlated with the decline in auto sales during the recession. Column 3 includes control variables; the magnitude of the credit card utilization rate declines, but it remains negative and statistically significant at the 10 percent level.

In columns 4 through 6 , we examine whether credit card utilization rates as of 2006 are related to the drop in housing permits or the increase in unemployment. Unlike the evidence on auto sales, we find little evidence of a correlation between credit card utilization rates and housing construction or unemployment. In other words, there is a large fraction of unexplained variation in housing permit growth and unemployment growth, especially after the third quarter of 2008.

\section{B. Alternative channels}

In this section, we consider other factors that may have been important in explaining the cross-sectional severity of the recession across U.S. counties. It is important to emphasize that alternative channels must be able to explain the crosssectional patterns we observe.

Whenever a financial crisis occurs simultaneously with a severe recession, there is a possibility that financial market difficulties have an accelerator effect through business credit availability and investment (Bernanke and Gertler, 1989). Indeed, the results in the previous subsection suggest a financial accelerator effect through consumer credit supply. However, one potential argument against our household leverage channel is a local financial accelerator effect: household defaults in a given county led to difficulties in the local banking sector which in turn led to a contraction of business credit. The channel was not households cutting back in the face of enormous debt burdens and reduced credit availability; instead, financial difficulties in the local banking sector led to the economic downturn.

We examine the local financial accelerator hypothesis in Table $8 .^{10}$ In columns 1 through 3 , we isolate the sample to 52 counties that have banks in the county with less than 10 percent of their total deposit base in the county. In other words, these counties have almost exclusively national banks that are unlikely to have large exposure to the household defaults within the county. Among these national bank counties, we see the exact same relation between the increase in household leverage from 2002 to 2006 and economic outcomes from 2006 to 2009. It is difficult to argue that local banking markets are driving the effect in these counties, given that the banks are major national players.

\footnotetext{
${ }^{10}$ Deposit data by county for each bank is constructed using the FDIC Summary of Deposit data. Data on chargeoffs and net income is from Call Report data.
} 
In columns 4 through 6, we include explicit control variables for charge-offs and net income for the banks that have branches in the county. The inclusion of such control variables does not change the coefficient estimates on leverage growth from 2002 to 2006. These results are inconsistent with the hypothesis that the effect of household leverage on county-level outcomes is due to a local financial accelerator operating through the business sector. More generally, a common argument for the severity of the recession of 2007 to 2009 is an aggregate contraction of credit to businesses. We are skeptical of this view for a number of reasons. First, non-residential business investment was the last main component of GDP to move in the cycle. Investment in equipment in software did not register a major decline until the fourth quarter of 2008, and the reduction in investment in structures did not begin until the first quarter of 2009. While the drop in investment in the last part of the recession may have been due to harsh credit conditions, it is just as likely that businesses cut investment in response to the dramatic reduction in consumption.

Second, businesses were in a much healthier financial situation than consumers as of the third quarter of 2008 when the credit crisis began. Indeed, the corporate debt to income ratio increased only moderately leading up to the recession (Mian and Sufi (2009b)). A large body of research documents shows how businesses used large revolving credit facilities extended during the credit boom to mitigate the impact of the credit crunch (Ivashina and Scharfstein, 2009; Gao and Yun. 2009; Chari et al.,2008). Survey evidence also suggests that there was absolutely no evidence of a credit crunch to small businesses through September 2008 (Dunkelburg, 2008)).

Third, while consumer defaults have skyrocketed above any level in recent history, direct measures of corporate distress were relatively low compared to the 2001 recession, even in the heart of the credit crunch in the fall of 2008. Figure 9 shows the fraction of public firms that are in violation of a financial covenant in any debt agreement (top panel) and the fraction of public firms in payment default of debt agreements (bottom panel). ${ }^{11}$ For the 2008 fiscal year (which covers firms filing their 10-K at any point from July 2008 to June 2009), the fraction of firms that violated a financial covenant is much lower than during the recession of 2001. While corporate defaults did eventually skyrocket in the second quarter of 2009, these defaults occurred very late in the recession. As of the fourth quarter of 2008, corporate defaults were much lower than during the years around the 2001

\footnotetext{
${ }^{11}$ The covenant violation data are described in detail in Nini et al. (2009). The corporate default data are from Moody's Default and Recovery Database.
} 
recession. Both covenant violation and default patterns suggest that firms faced less distress than they did in the relatively mild recession of 2001.

\section{How much of the recession does our model of household leverage explain?}

The severity of the 2007 to 2009 recession is reflected in four aggregate facts: (i) there was an extraordinary rise in household defaults from 4.1 percent to 9.7 percent, (ii) homeowners experienced a 21 percent drop in house prices, (iii) consumers pulled back sharply on durable consumption, which we proxy for with the 36 percent drop in auto sales, and (iv) the unemployment rate jumped from 4.2 percent to 9.8 percent. $^{12}$

How much of these four factors can the growth in household leverage from 2002 to 2006 and the level of consumer reliance on credit card borrowing as of 2006 explain? In other words, can the cross-sectional variation in these two measures of household leverage explain most of the aggregate fluctuations listed above?

A simple answer to this question is given by the predicted fluctuations for counties that score very low on our two measures of household leverage. ${ }^{13}$ For example, if household leverage growth from 2002 to 2006 were the only factor responsible for the dramatic increase in defaults, then we would predict zero increase in defaults for counties with no growth in leverage from 2002 to 2006. Using this methodology, our first factor - the growth in household leverage from 2002 to 2006 - accounts for almost the entire increase in household defaults and the entire decline in house prices. This can be seen in column 2 of Tables 2 and 3 where the constant in univariate regressions is very close to zero and precisely estimated. ${ }^{14}$

The constant in column 2 of Table 4 suggests that the leverage growth from 2002 to 2006 alone is not sufficient to explain the entire drop in auto sales from the end of 2006 to 2009. The regression predicts a 15 percent drop in auto sales even in counties for which there was no increase in household leverage. Given an average drop in auto sales of 36 percent, this estimate implies that our first factor cannot explain 42 percent $(=15 / 36)$ of the overall drop in auto sales.

\footnotetext{
${ }^{12}$ All of these numbers are calculated using our sample.

${ }^{13}$ By using predicted values, this magnitude assessment ignores unexplained (residual) variation. In other words, we compare magnitudes by using the economic outcomes that our model predicts for counties with varying degrees of household leverage, and ignoring any "unexplained" variation not predicted by our model.

${ }^{14}$ Counties in the lowest leverage growth decile have a change in the debt to income ratio from 2002 to 2006 just above zero. The constant, therefore represents an in sample prediction for these lowest decile leverage growth counties.
} 
However, the specification reported in column 2 of Table 7 shows that adding our second factor - the credit card utilization rate as of 2006 - significantly adds to our predictive power of explaining the auto sales decline. How much of the overall decline in auto sales can our two combined factors explain? This question can be answered by looking at the predicted auto sales decline for counties that score low on both household leverage growth and the credit card utilization rates. Counties in the bottom decile of household leverage growth from 2002 to 2006 and credit card utilization rate in 2006 have mean values for these two variables of 0.166 and 0.198, respectively. Using the coefficient estimates from column 2 of Table 7, the predicted auto sales decline for a county in the lowest decile of both our factors is 3.5 percent $(=-0.281 * 0.166-3.051 * 0.198+0.616)$. In other words, our model predicts almost no change in auto sales in the absence of the observed changes in leverage growth and the credit card utilization rate. ${ }^{15}$

Comparatively, our measures of household leverage within the model cannot explain as much of the aggregate rise in unemployment. For example, the estimates in column 2 of Table 6 imply that even counties with no increase in household leverage from 2002 to 2006 would have seen a rise in unemployment of 4.7 percent. Household leverage growth therefore explains only 1.1 percent of the 5.6 percent increase in aggregate unemployment. The estimates in column 6 of Table 7 show that the credit card utilization rate does not add much power in explaining the rise in unemployment.

However, the limitation of our cross-sectional measures of household leverage in explaining the aggregate rise in unemployment should not be seen as a failure of household leverage itself. Our earlier results - as well as aggregate patterns - show that a large part of the decline in GDP is driven by a drop in consumption, and in particular durable consumption. The drop is much more pronounced in areas that were more levered, either in terms of leverage growth or dependence on credit card borrowing. However, production of consumer goods is often not in the same county where consumers are located. As a result, we would naturally expect unemployment to be more evenly distributed across the country, even if household leverage is the underlying cause of the rise in unemployment. For example, a decline in auto sales due to high leverage growth in Florida and California would naturally lead to higher unemployment in other states such as Alabama and Michigan.

\footnotetext{
${ }^{15}$ We focus on the lowest decile counties, because we prefer to avoid out of sample predictions. We should point out however, that household leverage growth and credit card utilization rates are strongly negatively correlated with a correlation coefficient of -0.31 . Nonetheless there exist counties that lie in the intersection of bottom deciles for the two factors.
} 
As a cautionary note, our exercise is not meant to argue that household leverage "predicts" recessions. Instead, we examine only one recession. In this recession, our cross-sectional statistical model predicts that the increase in mortgage defaults and the decline in house prices and durable consumption would have been largely avoided had counties had low measures of household leverage as of 2006.

\section{Conclusion}

Understanding economic fluctuations is a central goal of macroeconomics. Our results suggest that the sharp increase in household leverage from 2002 to 2006 is closely linked to the 2007 to 2009 economic recession. Other factors in the financial markets — such as banks' liquidity, the Lehman bankruptcy, and policy uncertainty - may have contributed to the size of the downturn. However, our evidence lends support to the hypothesis that the initial economic slowdown was a result of a highly-leveraged household sector unable to keep pace with its debt obligations.

Our results are consistent with the following interpretation: As homeowners realized that house price appreciation was no longer sufficient to roll over existing debt, they borrowed aggressively from their existing unsecured credit limits, started to default, and, most importantly, cut back on durable consumption. These patterns began around the middle of 2006, well before the financial market turmoil of August 2007 or the deeper meltdown of the fall of 2008.

Our interpretation of the evidence is consistent with two other studies that rely on cross-sectional variation in household leverage. King (1994) examines GDP growth across western countries in the 1990 to 1991 recession and finds evidence that countries with higher household debt to GDP ratios before the recession had more severe declines in GDP. Glick and Lansing (2009) conduct a similar exercise for the 2007 to 2009 recession and find similar results. The similarity of the crosssectional evidence in these three different settings is strongly indicative of a close link between household leverage and economic downturns. The weight of the evidence suggests the need for more theoretical and empirical research on this potential channel.

\section{References}

Bernanke, Ben and Mark Gertler (1989). "Agency Costs, Net Worth, and Business Fluctuations.” American Economic Review, 79: 14-31. 
Chari, V., Lawrence Christiano, and Patrick Kehoe (2008). "Facts and Myths About the Financial Crisis of 2008.” Federal Reserve Bank of Minneapolis Research Departmen Working Paper No. 666.

Chrisitiano, L, R Motto and M Rostagno (2007). "Financial Factors in Business Cycles.” Mimeo, European Central Bank.

Demyanyk, Y., and Van Hemert, O (2009). "Understanding the Subprime Mortgage Crisis.” Review of Financial Studies, May.

Dunkelberg, William (2008). "Economic Responses to the Monetary Policy Signals of 2007: A Small Business Perspective." University of Michigan RSQE Conference Proceedings.

Fisher, Irving (1933). "The Debt-deflation Theory of Great Depressions." Econometrica, 1: 337-357.

Fisher, J. (2001). "Heterogeneous Investment Dynamics.” mimeo, Federal Reserve Bank of Chicago.

Gao, Pengjie and Hayong Yun (2009). "Commercial Paper, Lines of Credit, and the Real Effects of the Financial Crisis of 2008: Firm-Level Evidence from the Manufacturing Industry.” Available at SSRN: http://ssrn.com/abstract=1421908. Glick, Reuvan and Kevin Lansing (2009). "U.S. Household Deleveraging and Future Consumption Growth." Federal Reserve Bank of San Francisco Economic Letter, No. 2009-16, May 15, 2009.

Gross, David and Nicholas S. Souleles (2002). "Do Liquidity Constraints And Interest Rates Matter For Consumer Behavior? Evidence From Credit Card Data.” The Quarterly Journal of Economics, 117: 149-185.

Iacoviello, M. (2005). "House Prices, Borrowing Constraints and Monetary Policy in the Business Cycle.” American Economic Review, 95, 739-64.

Ivashina, Victoria and David Scharfstein (2009). "Bank Lending during the Financial Crisis of 2008." Available at SSRN: http://ssrn.com/abstract $=1297337$.

Keys, Benjamin, Tanmoy Mukherjee, Amit Seru, and Vikrant Vig (2010). "Did Securitization Lead to Lax Screening: Evidence from Subprime Loans." Quarterly Journal of Economics, 125.

King, Mervyn (1994). "Debt Deflation: Theory and Evidence." European Economic Review, 38: 419-455.

Kiyotaki, Nobuhiro, and John Moore (1997). “Credit Cycles.” Journal of Political Economy, 105, 211-248.

Leamer, Edward (2009). "Macroeconomic Patterns and Stories: A Guide for MBAs.” Springer Publications.

Leamer, Edward (2007). "Housing is the Business Cycle.” NBER Working Paper 13428.

Leonnig, Carol D. (2008). "How HUD Mortgage Policy Fed the Crisis." Washington Post, June 10. 
Mayer, Christopher and R. Glenn Hubbard (2008). "House Prices, Interest Rates, and the Mortgage Market Meltdown.” Working Paper, Columbia GSB.

Mian, Atif R. and Sufi, Amir (2009a). "The Consequences of Mortgage Credit Expansion: Evidence from the U.S. Mortgage Default Crisis.” Quarterly Journal of Economics 124.

Mian, Atif. R. and Sufi, Amir (2009b). "House Prices, Home Equity-based Borrowing, and the U.S. Household Leverage Crisis.” NBER Working Paper 15283.

Mishkin, Frederic (1978). "The Household Balance Sheet and the Great Depression.” Journal of Economic History, 38: 918-937.

Nini, Greg, David Smith and Amir Sufi (2009). "Creditor Control Rights, Corporate Governance, and Firm Value." Working Paper, Available at http://gates.comm.virginia.edu/dcs8f/Nini,\%20Smith,\%20Sufi\%20November\% 202010.pdf.

Obstfeld, Maurice and Kenneth Rogoff (2009). "Global Imbalances and the Financial Crisis: Products of Common Causes." Federal Reserve Bank of San Francisco Asia Economic Policy Conference Paper.

Saiz, Albert (2008). “On Local Housing Supply Elasticity.” Working Paper: SSRN No. 1193422.

Tovar, Camilo E. (2008). "DSGE Models and Central Banks.” BIS Working Paper No 258. 
Figure 1. Household Leverage and the U.S. Recession of 2007 to 2009

The top panel plots the unemployment rate according to the Bureau of Labor Statistics, and the middle panel plots GDP growth from NIPA. The bottom panel plots the aggregate household debt to income ratio for the U.S. from 1977 to 2008. Household debt data come from the Federal Reserve's Flow of Funds, income represents wage and salary payments from the National Income and Product Accounts (NIPA).
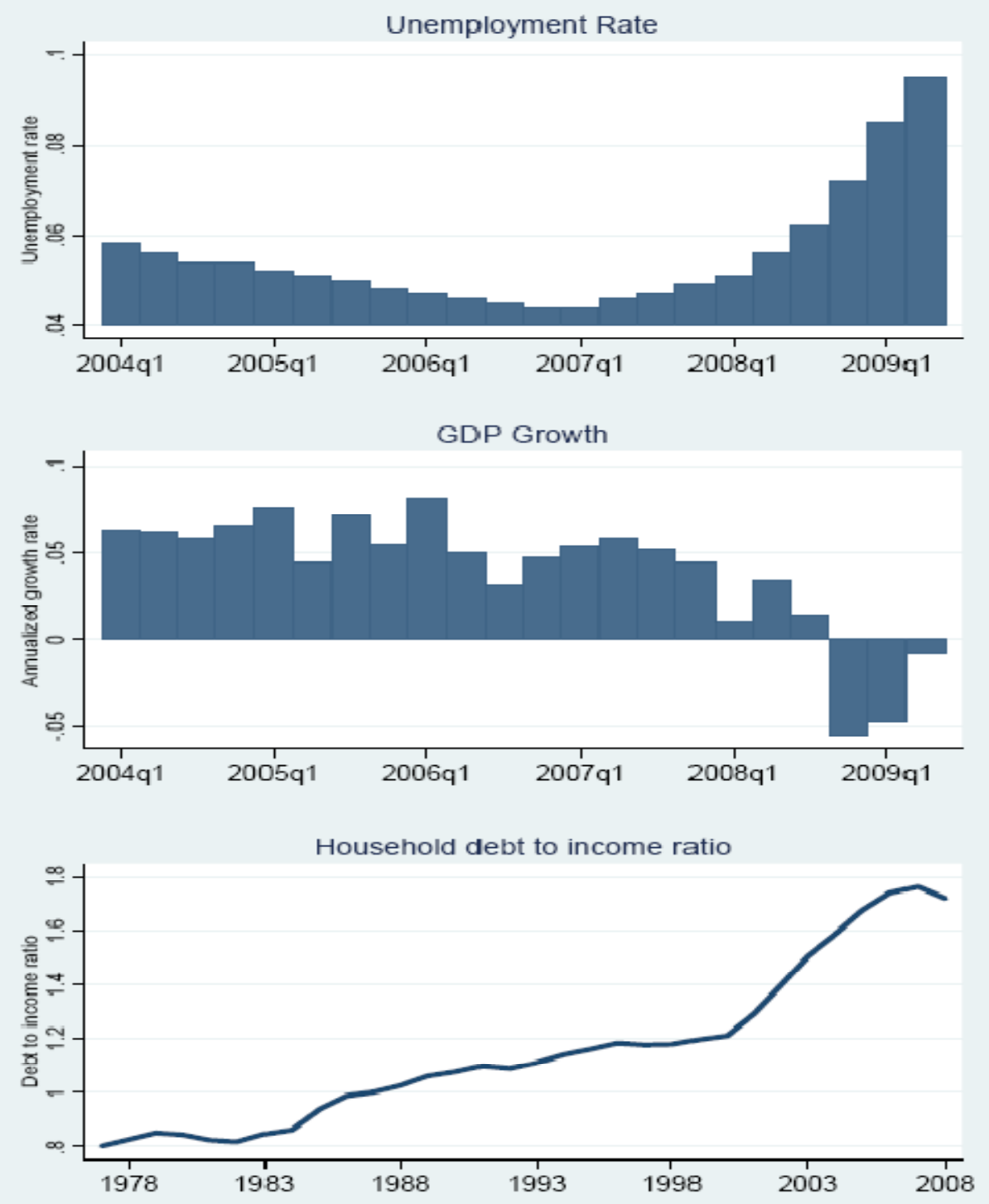
Figure 2. Weakness of Household Balance Sheets

The top panel presents default rate data from Equifax and house price data from the Case Shiller 20 MSA house price index. The house price series represents the cumulative growth since the fourth quarter of 2005. The bottom panel plots household debt growth from Equifax since 2005 and the personal savings rate from NIPA.

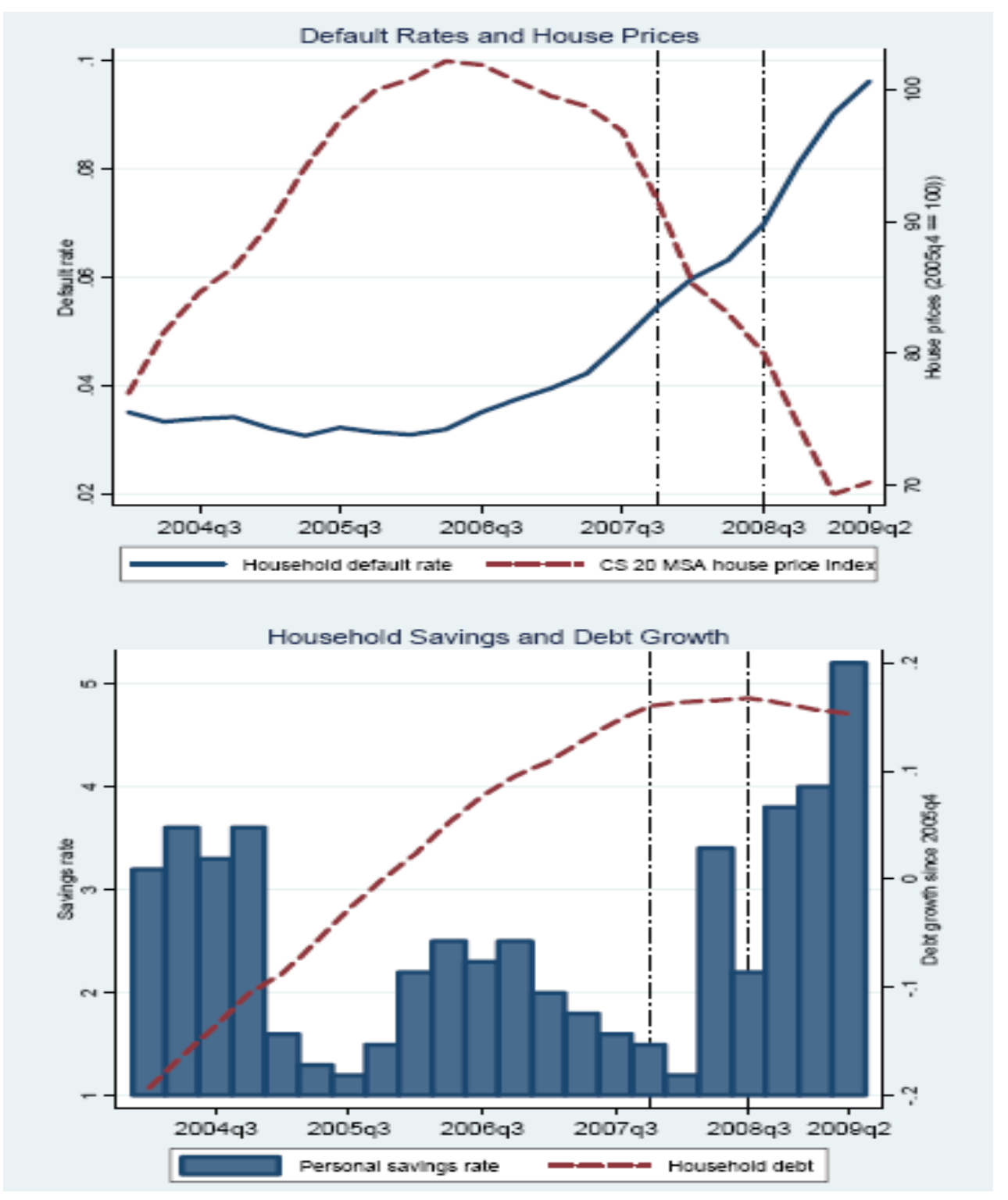


Figure 3. Household Defaults and Unemployment

Household default rate data comes from Equifax and the unemployment data are from the BLS.
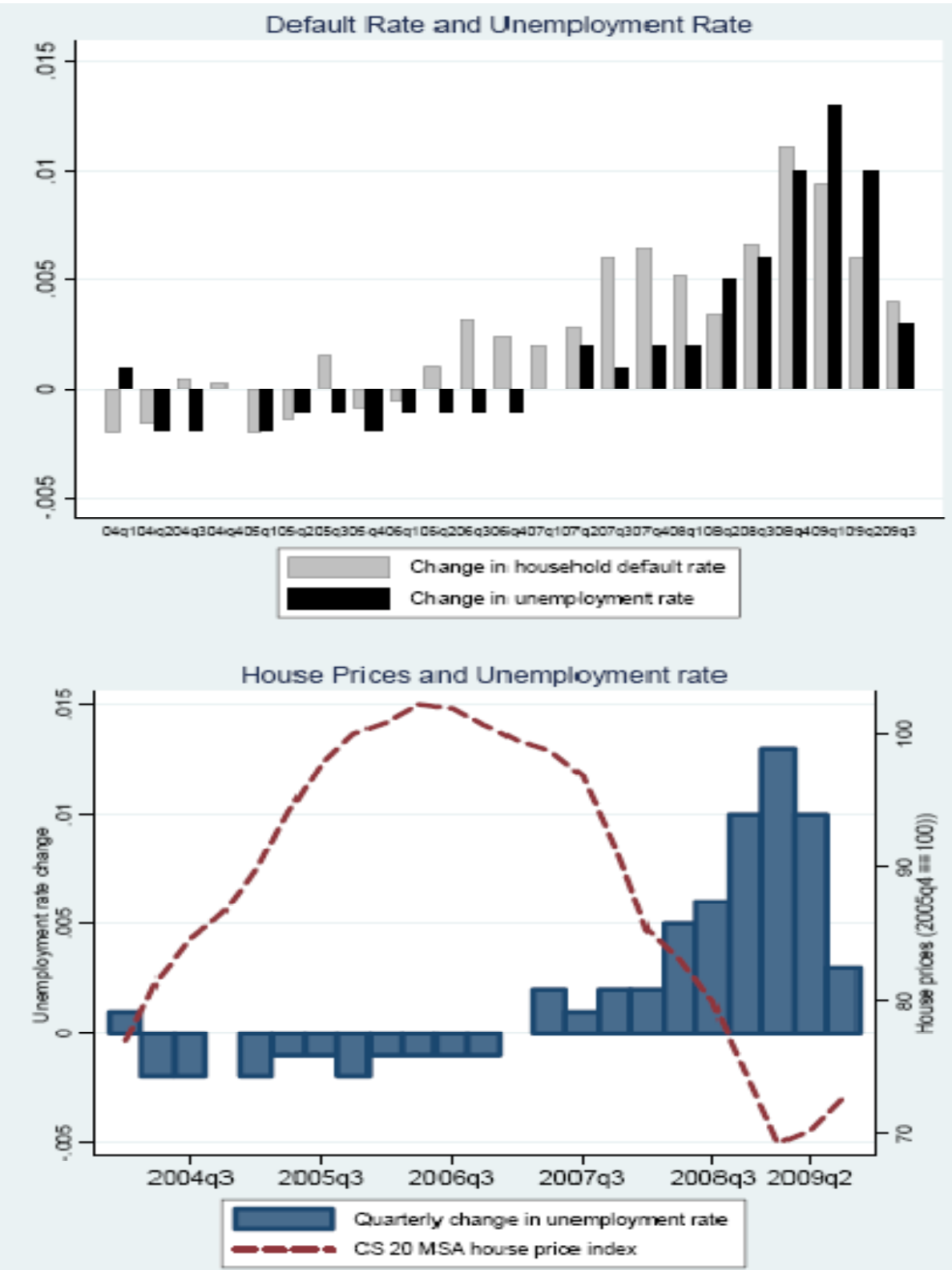
Figure 4. What Components of GDP Moved First?

The top two panels present investment and consumption data from NIPA. The bottom panel presents monthly retail sales data from the Department of Commerce. Each series represents the cumulative growth rate since the fourth quarter of 2005.
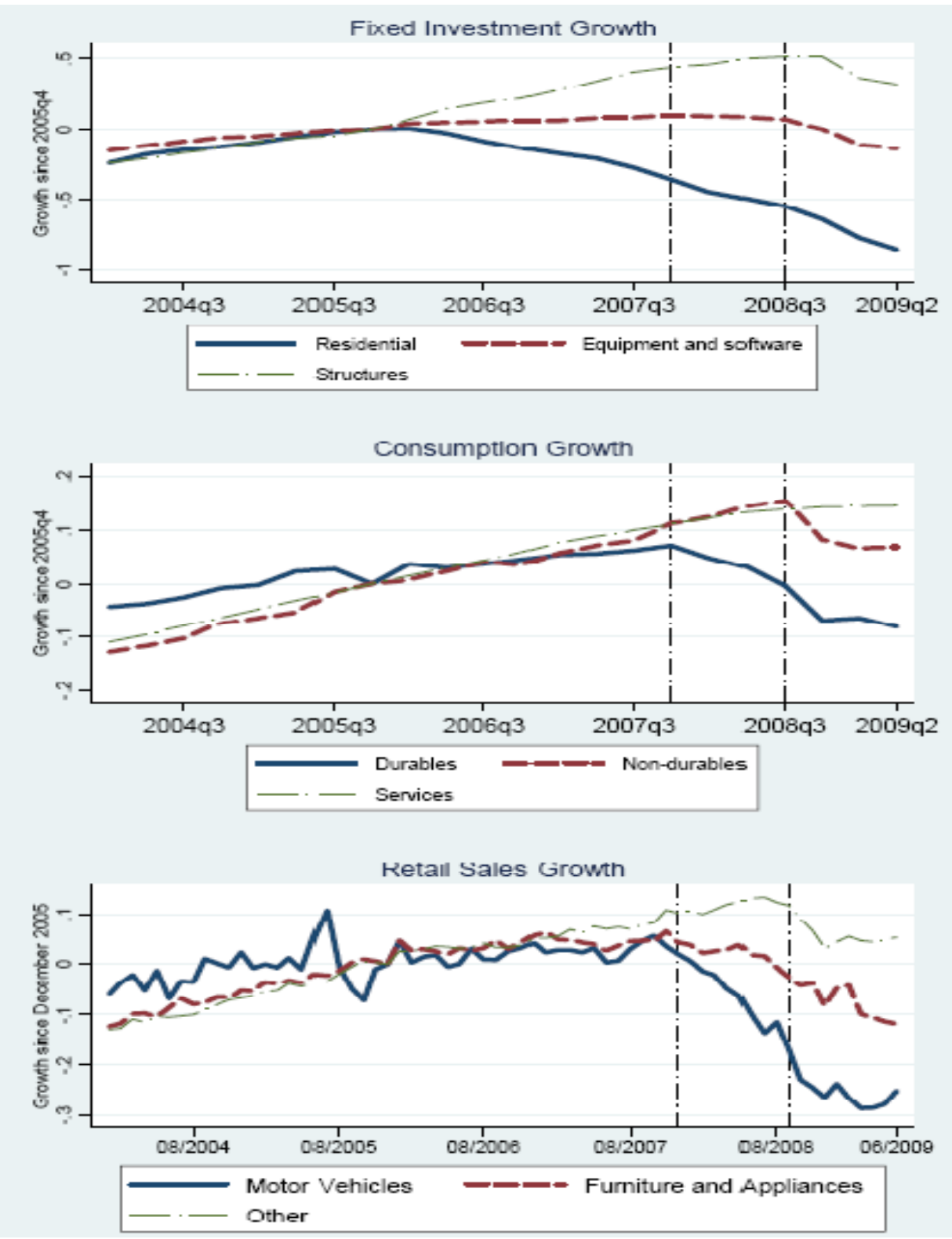
Figure 5A. Default Rates and House Price Growth in High and Low Leverage Growth Counties

High leverage growth counties are defined to be the top 10 percent of counties by the increase in the debt to income ratio from 2002Q4 to 2006Q4. Low leverage growth counties are in the bottom 10 percent based on the same measure. The left panel plots the change in the default rate for high and low leverage growth counties since 2005, and the right panel plots the growth rate for high and low leverage growth counties since 2005.
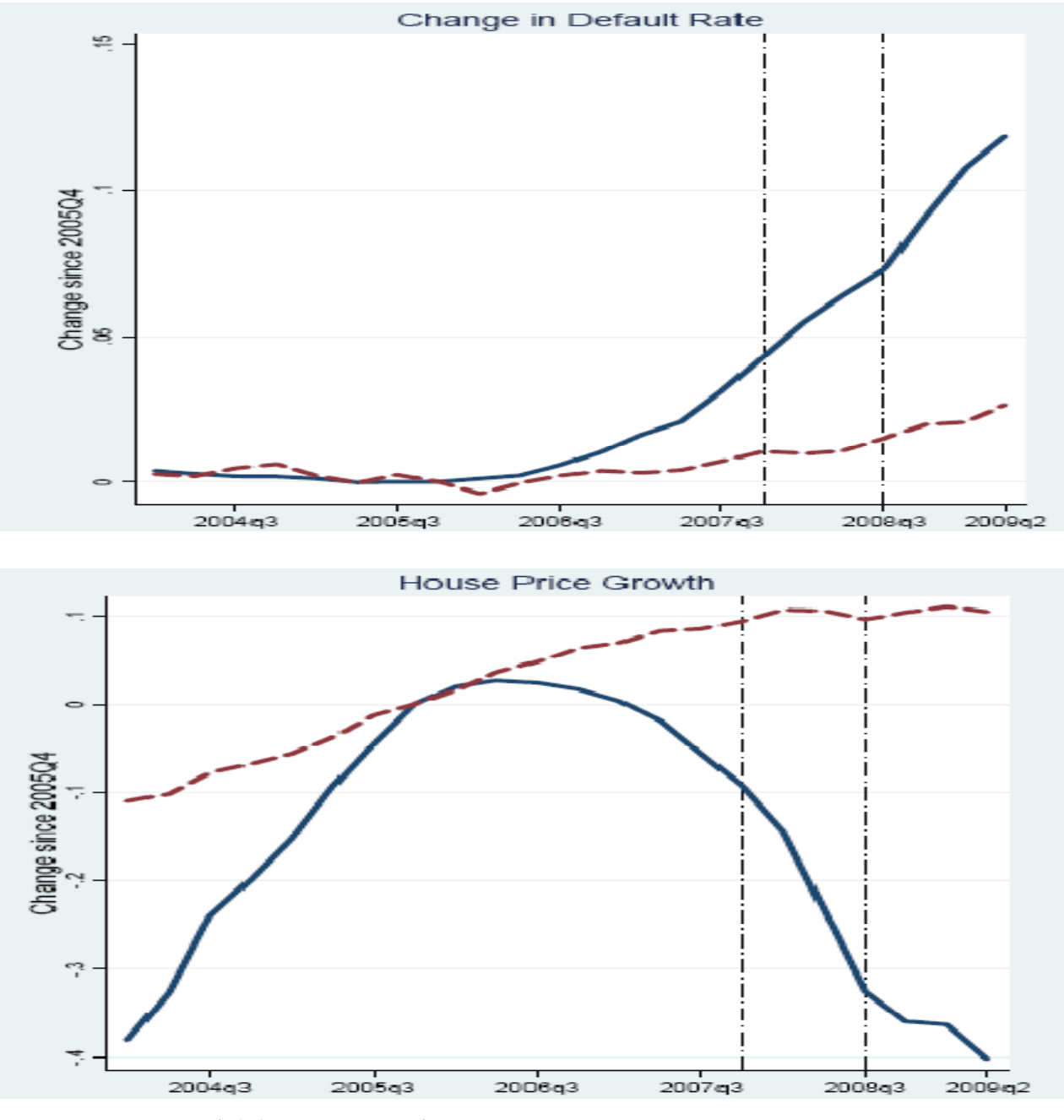

High leverage countries 
Figure 5B. Correlation across Counties of Default Rates and House Prices during Recession with Leverage Growth from 2002 to 2006

The left panel presents the correlation across U.S. counties of the increase in the household debt to income ratio from 2002Q4 to 2006Q4 and the increase in the default rate from 2006Q4 to 2009Q2. The right panel presents the correlation across U.S. counties of the increase in the household debt to income ratio from 2002Q4 to 2006Q4 and the decline in house prices from 2006Q2 to 2009Q2. The sample includes 450 counties with at least
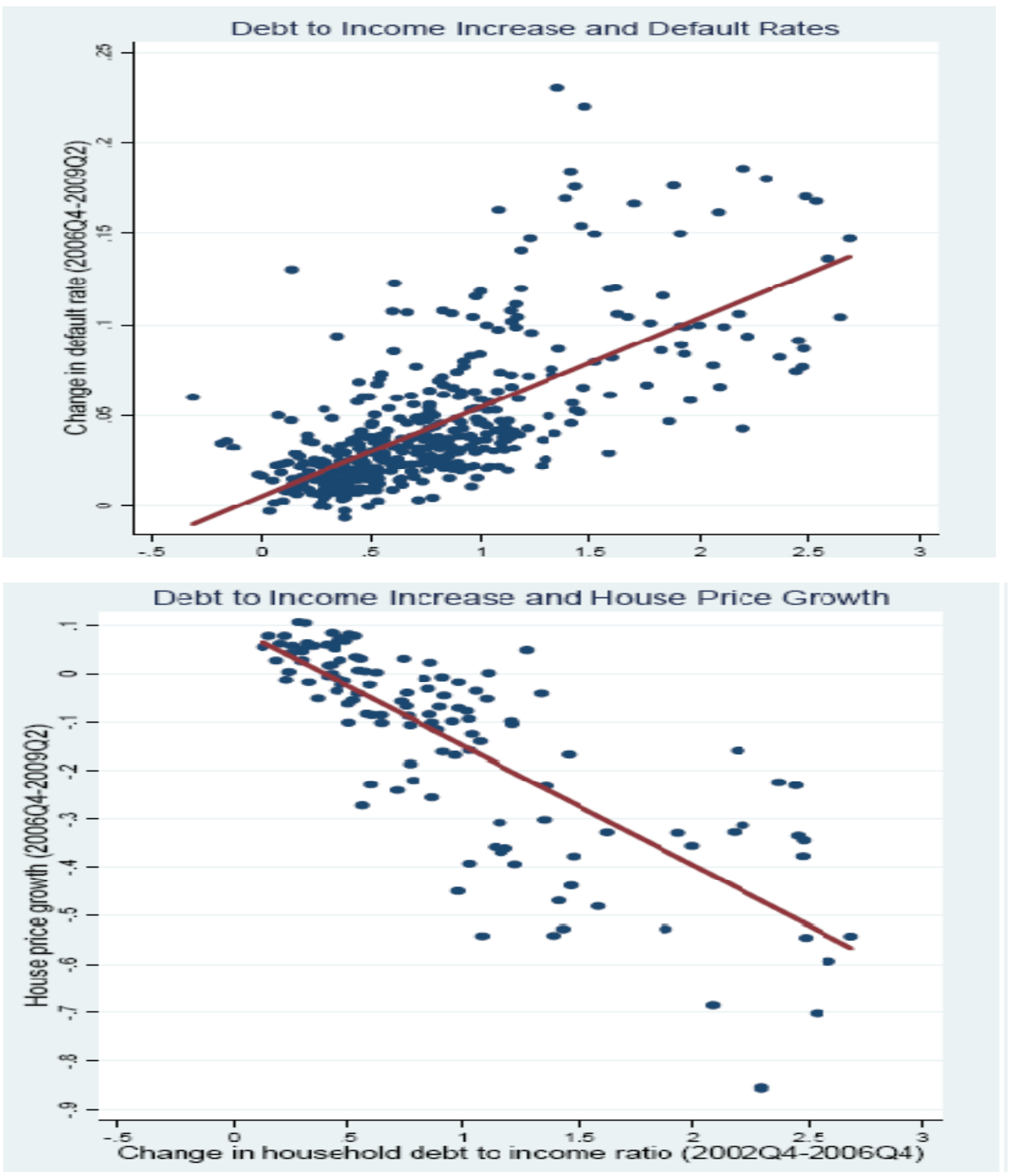
Figure 6A. Auto Sales, New Home Building, and Unemployment Rates in High and Low Leverage Growth Counties

High leverage growth counties are defined to be the top 10 percent of counties by the increase in the debt to income ratio from 2002Q4 to 2006Q4. Low leverage growth counties are in the bottom 10 percent based on the same measure. The left panel plots the growth in auto sales since 2005, the middle panel plots the growth in new housing permits since 2005, and the right panel plots the change in the unemployment rate since 2005.

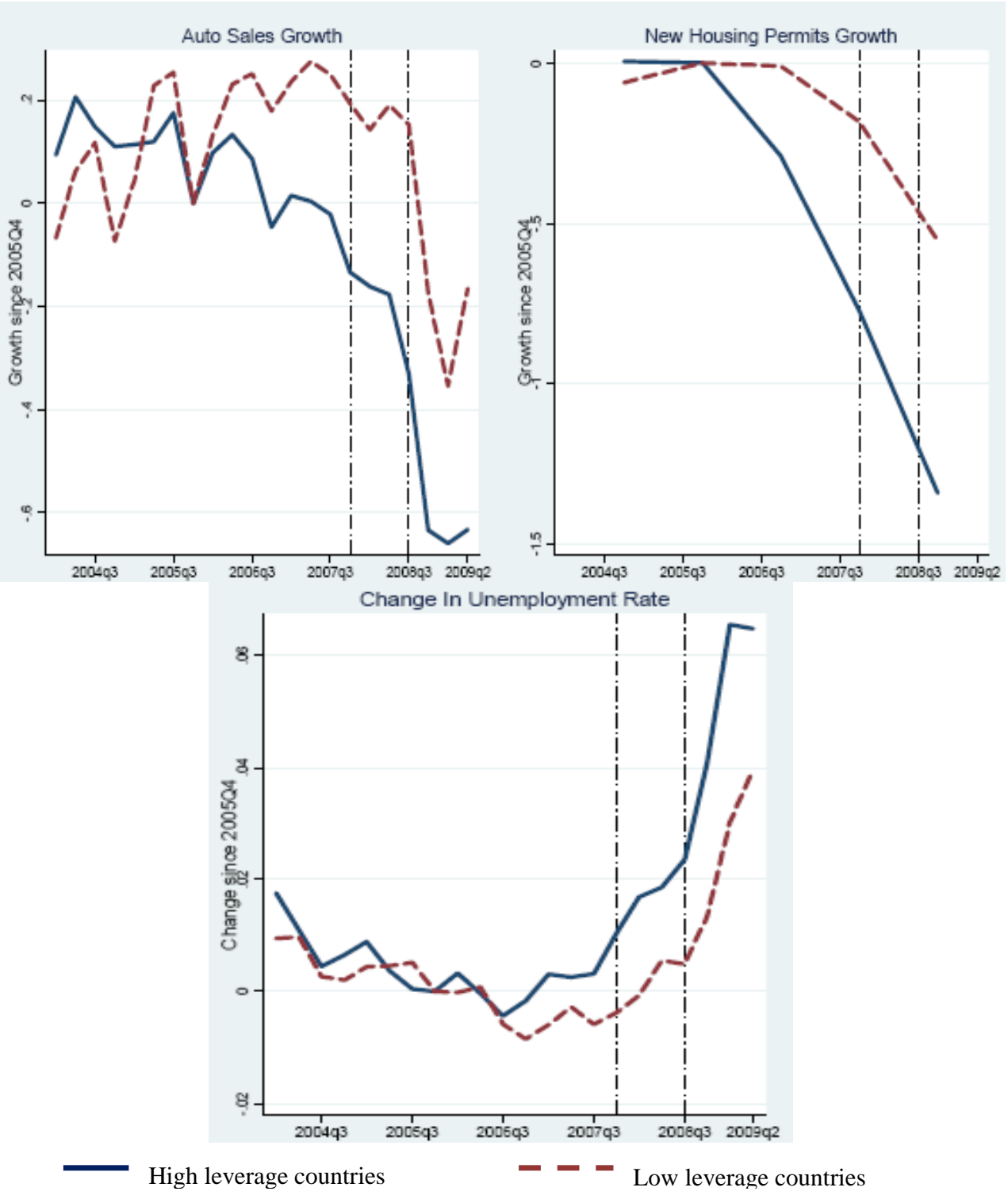


Figure 6B. Correlation across Counties of Auto Sales, New Housing Permits, and Unemployment during Recession with Leverage Growth from 2002-2006

The left panel presents the correlation across U.S. counties of the increase in the household debt to income ratio from 2002Q4 to 2006Q4 and the decline in auto sales from 2006Q4 to 2009Q2. The middle panel presents the correlation of the increase in the household debt to income ratio from 2002Q4 to 2006Q4 and the growth in housing permits from 2006 to 2008. The right panel presents the correlation across U.S. counties of the increase in the household debt to income ratio from 2002Q4 to 2006Q4 and the increase in unemployment rates from 2006Q2 to 2009Q2. All y axis variables are winsorized at the 1 percent level. The sample includes 450 counties with at least 50,000 households as of 2000.
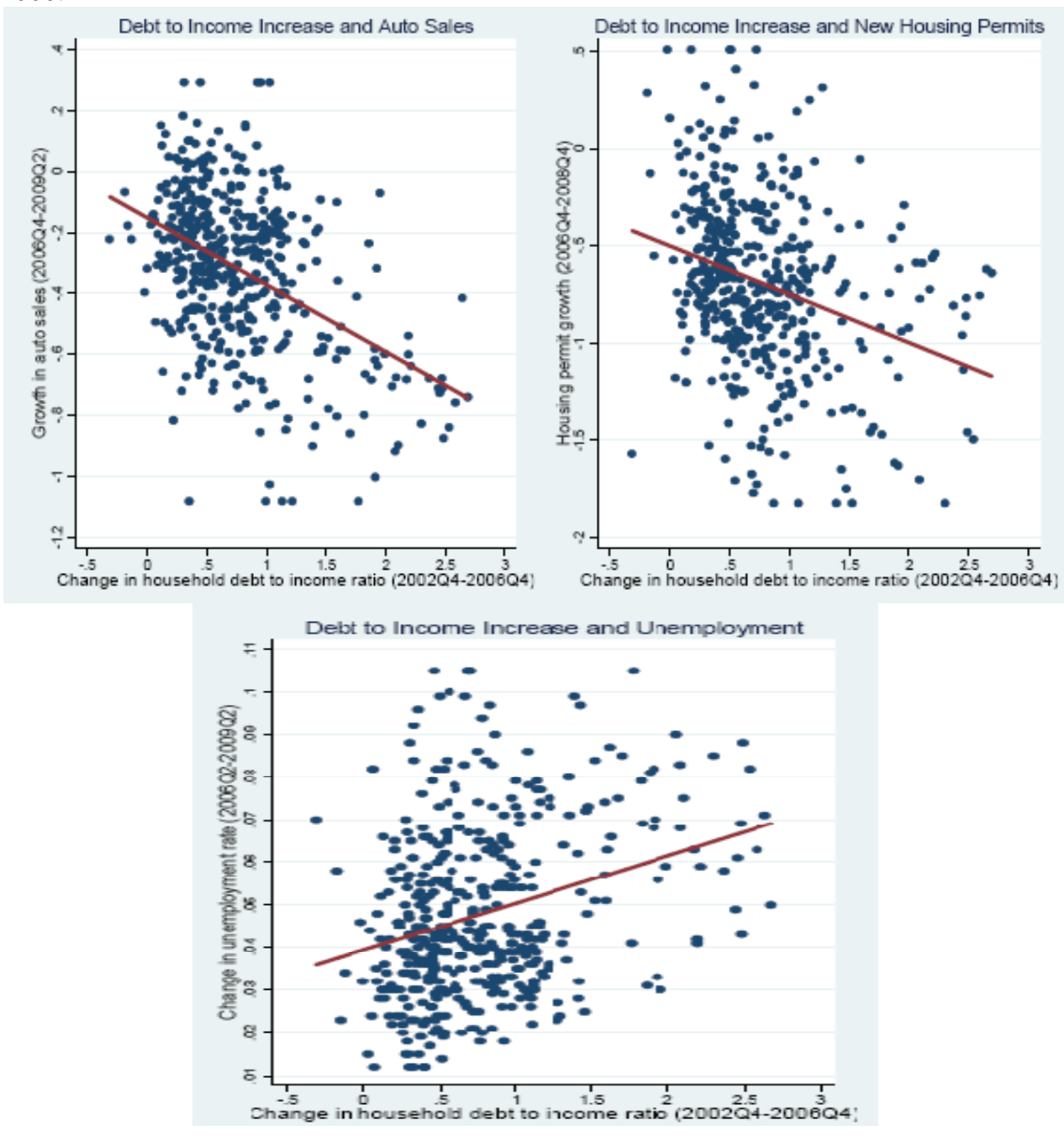


\section{Figure 7. Credit Lines during the Recession}

High leverage growth counties are defined to be the top 10 percent of counties by the increase in the debt to income ratio from 2002Q4 to 2006Q4. Low leverage growth counties are in the bottom 10 percent on the same measure. The panels of this figure present evidence on home equity and credit card limits, draw-downs, and utilization rates from 2004Q4 to 2009Q2 for high and low leverage growth counties.
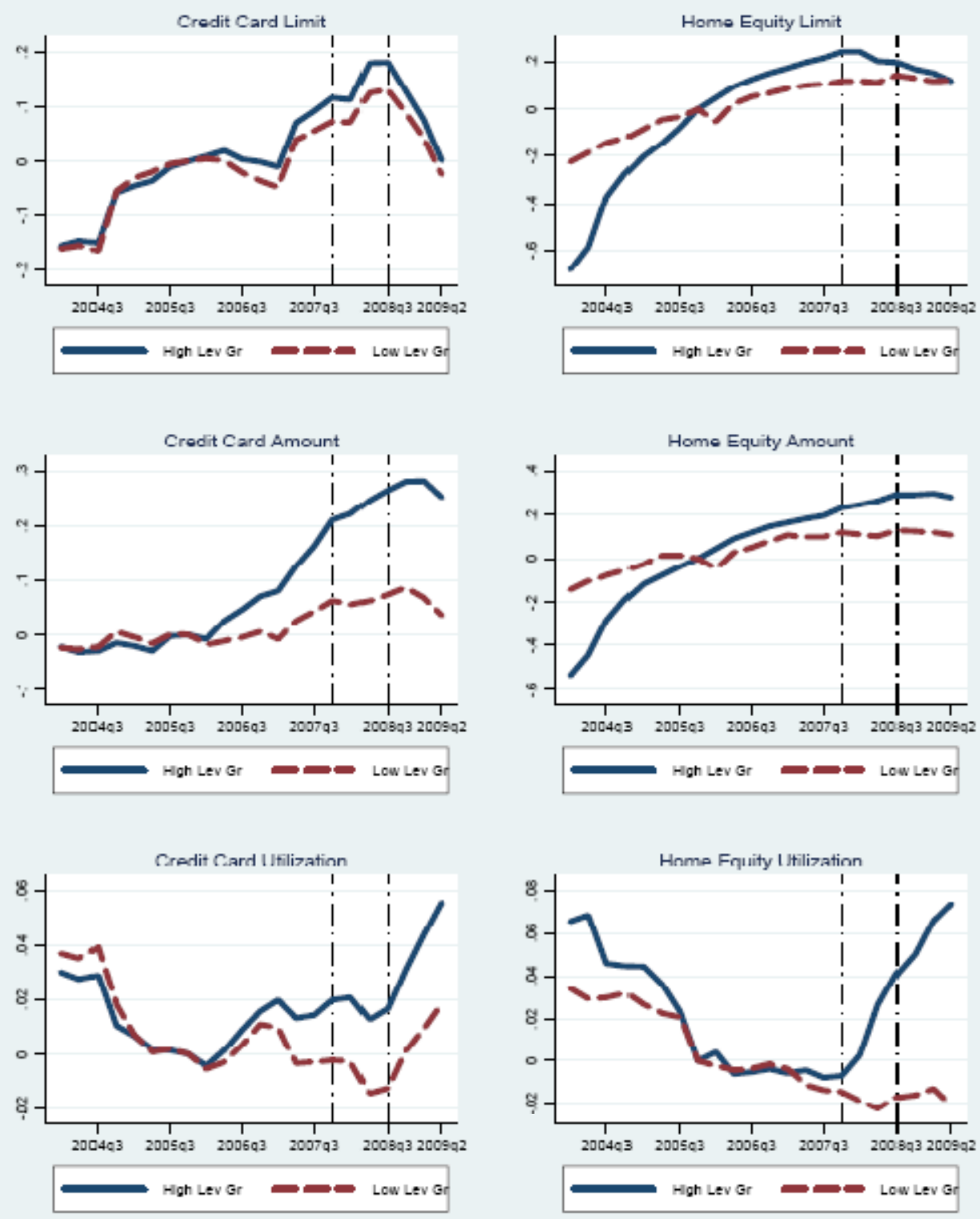
Figure 8. Consumer Credit Constraints and the Severe Contraction from 2008Q3 to 2009Q2

The top panel presents the correlation across counties between auto sales growth from 2008Q3 to 2009Q2 and the credit card utilization rate as of 2006Q4. The bottom panel presents the correlation across counties between the change in the unemployment rate from 2008Q3 to 2009Q2 and the credit card utilization rate as of 2006Q4. All variables are winsorized at the 1 percent level.
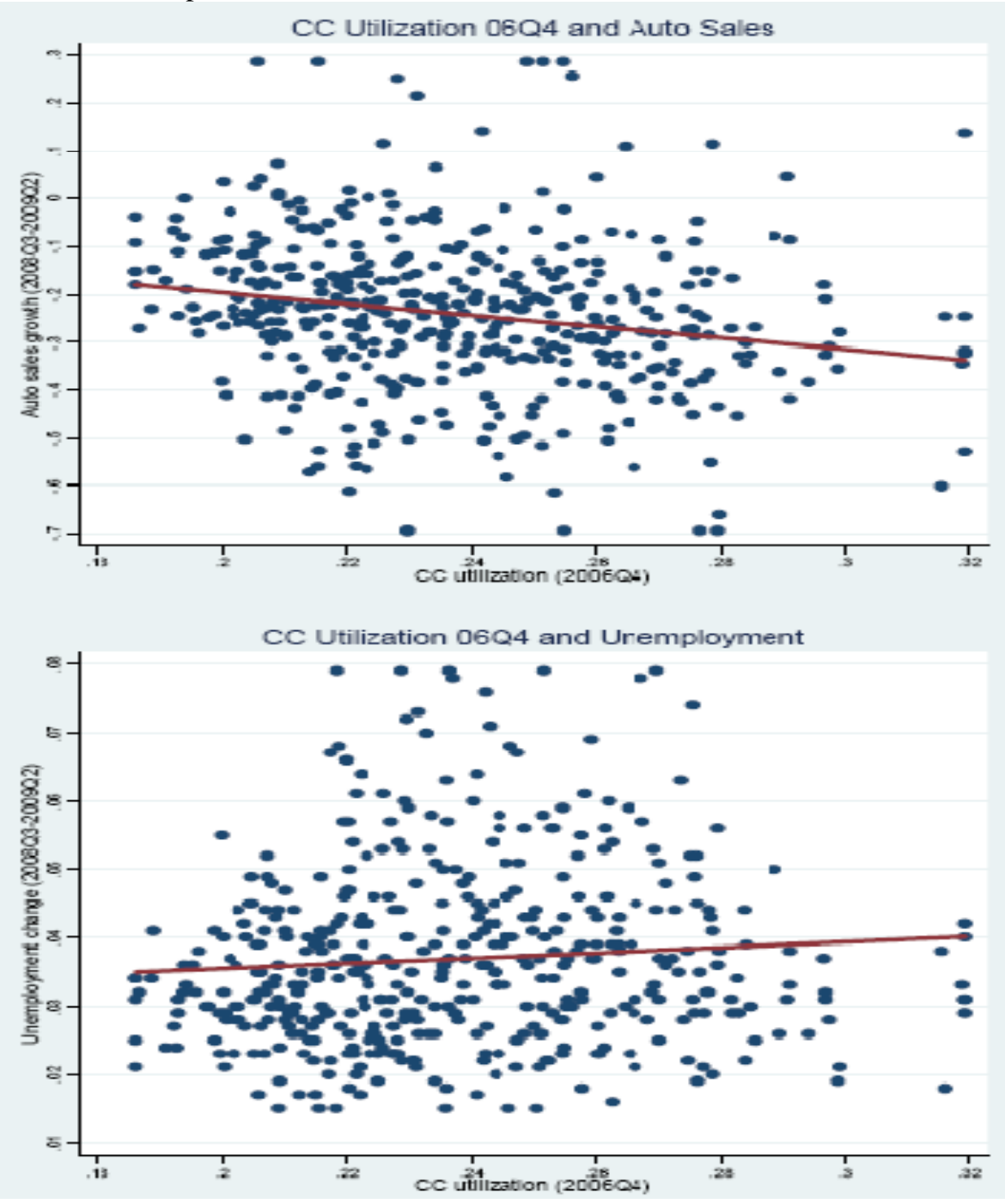
Figure 9. Measures of Financial Distress for U.S. Corporations

Covenant violation data for U.S. publicly traded corporations are from Nini, Smith, and Sufi (2009). Corporate default data are for U.S. publicly traded corporations and come from Moody's Default and Recovery Database.
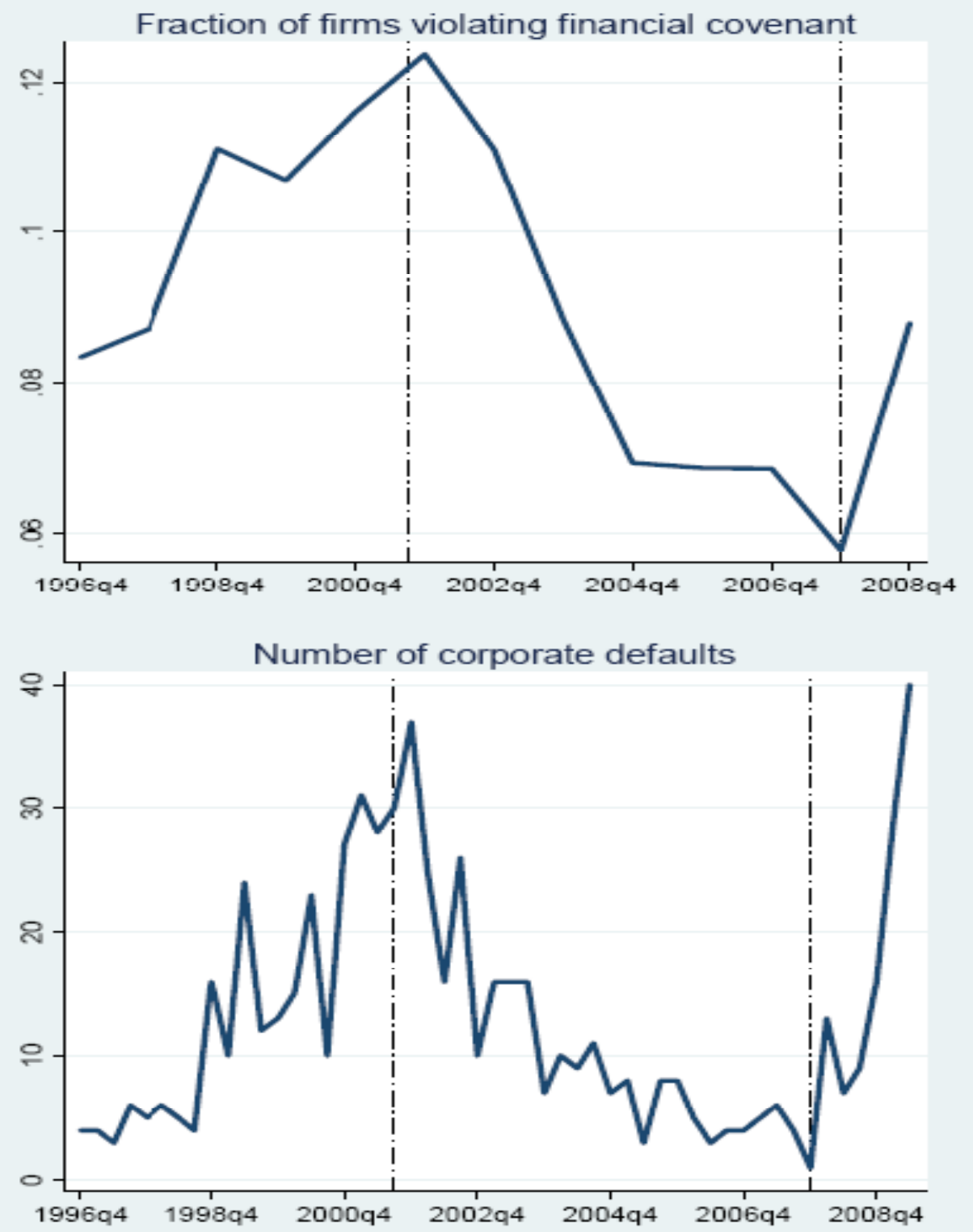
Table 1. Summary Statistics for U.S. Counties

This table presents summary statistics for the 450 counties in our sample. We include only counties that have at least 50,000 households as of the 2000 Decennial Census.

\begin{tabular}{|c|c|c|c|c|c|c|}
\hline & $\mathrm{N}$ & Mean & Median & SD & $10^{\text {th }}$ & $90^{\text {th }}$ \\
\hline \multicolumn{7}{|l|}{ Equifax credit bureau/IRS income } \\
\hline Debt to income increase, '02Q4 to '06Q4 & 450 & 0.775 & 0.668 & 0.53 & 0.256 & 1.46 \\
\hline Debt to income, '01Q4 & 450 & 2.211 & 2.084 & 0.533 & 1.615 & 2.995 \\
\hline \multicolumn{7}{|l|}{ Equifax credit bureau } \\
\hline Change in default rate, ' $06 q 4$ to '09q2 & 450 & 0.043 & 0.032 & 0.039 & 0.01 & 0.099 \\
\hline Default rate, '06Q4 & 450 & 0.041 & 0.039 & 0.015 & 0.023 & 0.058 \\
\hline Default rate, ‘01Q4 & 450 & 0.04 & 0.04 & 0.02 & 0.02 & 0.06 \\
\hline Fraction with credit score below 660, '01Q4 & 450 & 0.33 & 0.32 & 0.09 & 0.24 & 0.46 \\
\hline Credit card utilization rate, ‘06Q4 & 450 & 0.24 & 0.23 & 0.03 & 0.21 & 0.28 \\
\hline \multicolumn{7}{|l|}{ FHFA house price index } \\
\hline House price growth, ’06Q4 to '09Q2 & 123 & -0.14 & -0.07 & 0.20 & -0.45 & 0.06 \\
\hline \multicolumn{7}{|l|}{ R.L. Polk auto sales } \\
\hline Auto sales growth, ’06Q4 to '09Q2 & 450 & -0.32 & -0.28 & 0.27 & -0.68 & -0.02 \\
\hline \multicolumn{7}{|l|}{ Census New Housing Permits } \\
\hline New house permit growth, ’06Q4 to ‘09Q2 & 449 & -0.69 & -0.69 & 0.46 & -1.24 & -0.14 \\
\hline \multicolumn{7}{|l|}{ Bureau of Labor Statistics } \\
\hline Change in unemployment rate, ’06Q4 to '09Q2 & 450 & 0.05 & 0.05 & 0.02 & 0.03 & 0.08 \\
\hline Unemployment rate, ‘06Q4 & 450 & 0.04 & 0.04 & 0.01 & 0.03 & 0.06 \\
\hline Unemployment rate, ‘01Q4 & 450 & 0.05 & 0.05 & 0.02 & 0.04 & 0.07 \\
\hline \multicolumn{7}{|l|}{ Decennial Census } \\
\hline Total households, '00 (thousands) & 450 & 182.00 & 104.00 & 246.00 & 55.00 & 355.00 \\
\hline Fraction black, ‘ 00 & 450 & 0.09 & 0.05 & 0.12 & 0.00 & 0.25 \\
\hline Fraction homeowner, ‘00 & 450 & 0.71 & 0.73 & 0.10 & 0.59 & 0.81 \\
\hline Fraction with high school education or less, ' 00 & 450 & 0.30 & 0.30 & 0.07 & 0.21 & 0.39 \\
\hline Ln (Median household income, ‘00) & 450 & 10.72 & 10.71 & 0.24 & 10.42 & 11.04 \\
\hline Ln(Median home value, ’00) & 450 & 11.69 & 11.63 & 0.43 & 11.19 & 12.28 \\
\hline \multicolumn{7}{|l|}{ Census County Business Patterns } \\
\hline Employment share in construction, ‘06Q4 & 449 & 0.07 & 0.06 & 0.03 & 0.04 & 0.11 \\
\hline Employment share in real estate, '06Q4 & 449 & 0.02 & 0.02 & 0.01 & 0.01 & 0.03 \\
\hline Employment share in finance, '06Q4 & 449 & 0.05 & 0.04 & 0.03 & 0.03 & 0.08 \\
\hline Employment share in retail, '06Q4 & 449 & 0.15 & 0.15 & 0.03 & 0.11 & 0.19 \\
\hline Employment share in exports, '06Q4 & 450 & 1.51 & 0.00 & 2.63 & 0.00 & 4.99 \\
\hline
\end{tabular}


Table 2. Household Leverage Increase from 2002Q4 to 2006Q4 and Default Rates from 2006Q4 to 2009Q2

The regression in columns 2 through 5 are weighted by the number of households in the county as of 2000. Column 5 reports coefficients from the second stage of an IV specification where the change in the debt to income ratio from 2002 to 2006 is instrumented with housing supply inelasticity of the county as constructed by Saiz (2008). Standard errors are clustered by state.

Dependent variable: Change in default rates, '06Q4 to '09Q2

(1)

(2)

(3)

(4) (5)

\begin{tabular}{|c|c|c|c|c|c|}
\hline & Unweighted & Weighted & Weighted & Weighted & $\begin{array}{l}\text { Weighted } \\
\text { IV }\end{array}$ \\
\hline \multirow[t]{2}{*}{ Change in debt to income, '02 to '06 } & $0.049 * *$ & $0.058 * *$ & $0.056^{* *}$ & $0.055^{* *}$ & $0.093^{* *}$ \\
\hline & $(0.008)$ & $(0.009)$ & $(0.009)$ & $(0.009)$ & $(0.025)$ \\
\hline \multirow[t]{2}{*}{ Debt to income, '01 } & & & $0.020^{* *}$ & $0.015^{*}$ & 0.01 \\
\hline & (23) & & $(0.006)$ & $(0.006)$ & $(0.01)$ \\
\hline \multirow[t]{2}{*}{ Unemployment rate, ‘06 } & & & -0.782 & -0.52 & $-0.986^{*}$ \\
\hline & & & $(0.474)$ & $(0.429)$ & $(0.429)$ \\
\hline \multirow[t]{2}{*}{ Unemployment rate, ‘01 } & & & $0.850 * *$ & $0.767 *$ & $1.134^{* *}$ \\
\hline & & & $(0.313)$ & $(0.301)$ & $(0.349)$ \\
\hline \multirow[t]{2}{*}{ Default rate, ‘06 } & & & -0.171 & -0.228 & -0.486 \\
\hline & & & $(0.246)$ & $(0.259)$ & $(0.323)$ \\
\hline \multirow[t]{2}{*}{ Default rate, ‘01 } & & & $1.280^{* *}$ & $1.232^{* *}$ & $1.642 * *$ \\
\hline & & & $(0.342)$ & $(0.36)$ & $(0.388)$ \\
\hline \multirow[t]{2}{*}{$\begin{array}{l}\text { Fraction with credit score under } 660 \text {, } \\
\text { ‘01 }\end{array}$} & & & $0.245^{* *}$ & $0.239 * *$ & 0.093 \\
\hline & & & $(0.075)$ & $(0.082)$ & $(0.131)$ \\
\hline \multirow[t]{2}{*}{ Credit card utilization rate, '06 } & & & $-0.628 * *$ & $-0.610 * *$ & -0.232 \\
\hline & & & $(0.13)$ & $(0.138)$ & $(0.325)$ \\
\hline \multirow[t]{2}{*}{ Fraction black, '00 } & & & $-0.066^{* *}$ & $-0.063^{*}$ & $-0.049+$ \\
\hline & & & $(0.025)$ & $(0.025)$ & $(0.027)$ \\
\hline \multirow[t]{2}{*}{ Fraction homeowner, '00 } & & & $-0.074 *$ & -0.049 & -0.088 \\
\hline & & & $(0.031)$ & $(0.036)$ & $(0.054)$ \\
\hline \multirow[t]{2}{*}{ Fraction with high school or less, '00 } & & & $0.116^{*}$ & $0.131^{*}$ & $0.241^{* *}$ \\
\hline & & & $(0.053)$ & $(0.05)$ & $(0.065)$ \\
\hline \multirow[t]{2}{*}{ Ln (Median household income, '00) } & & & $0.081^{* *}$ & $0.072^{* *}$ & $0.104^{* *}$ \\
\hline & & & $(0.022)$ & $(0.022)$ & $(0.033)$ \\
\hline Ln(Median home value, ’00) & & & $-0.021+$ & -0.018 & $-0.052 *$ \\
\hline
\end{tabular}




\begin{tabular}{|c|c|c|c|c|c|}
\hline & & & $(0.012)$ & $(0.012)$ & $(0.021)$ \\
\hline \multirow[t]{2}{*}{$\begin{array}{l}\text { Employment share in construction, } \\
\text { '06 }\end{array}$} & & & & 0.101 & -0.059 \\
\hline & & & & $(0.107)$ & $(0.114)$ \\
\hline \multirow[t]{2}{*}{ Employment share in real estate, '06 } & & & & $0.770^{*}$ & $0.960 *$ \\
\hline & & & & $(0.382)$ & $(0.425)$ \\
\hline \multirow[t]{2}{*}{ Employment share in finance, ‘06 } & & & & 0.066 & 0.066 \\
\hline & & & & $(0.056)$ & $(0.096)$ \\
\hline \multirow[t]{2}{*}{ Employment share in retail, '06 } & & & & -0.048 & -0.062 \\
\hline & & & & $(0.062)$ & $(0.094)$ \\
\hline \multirow[t]{2}{*}{ Employment share in exports, '06 } & & & & -0.001 & 0 \\
\hline & & & & $(0.001)$ & $(0.001)$ \\
\hline \multirow[t]{2}{*}{ Constant } & $0.005+$ & 0.005 & $-0.630 * *$ & $-0.595^{* *}$ & $-0.617^{*}$ \\
\hline & $(0.003)$ & $(0.005)$ & $(0.153)$ & $(0.153)$ & $(0.238)$ \\
\hline Number of counties & 450 & 450 & 450 & 449 & 218 \\
\hline $\mathrm{R}^{2}$ & 0.45 & 0.49 & 0.76 & 0.77 & 0.77 \\
\hline
\end{tabular}

**,*,+ Coefficient estimate statistically distinct from 0 at the $1 \%, 5 \%$, and $10 \%$ levels, respectively. 
Table 3. Household Leverage Increase from 2002Q4 to 2006Q4 and House Price Growth from 2006Q4 to 2009Q2

The regression in columns 2 through 5 are weighted by the number of households in the county as of 2000. Column 5 reports coefficients from the second stage of an IV specification where the change in the debt to income ratio from 2002 to 2006 is instrumented with housing supply inelasticity of the county as constructed by Saiz (2008). Standard errors are clustered by state.

Dependent variable: House price growth, '06Q4 to '09Q2
(1)
(2)
(3)
(4)
(5)

\begin{tabular}{|c|c|c|c|c|c|}
\hline & Unweighted & Weighted & Weighted & Weighted & Weighted IV \\
\hline \multirow[t]{2}{*}{ Change in debt to income, '02 to '06 } & $-0.247 * *$ & $-0.235^{* *}$ & $-0.221 * *$ & $-0.221 * *$ & -0.553 \\
\hline & $(0.024)$ & $(0.032)$ & $(0.036)$ & $(0.035)$ & $(0.574)$ \\
\hline \multirow[t]{2}{*}{ Debt to income, '01 } & & & $-0.117^{*}$ & $-0.079+$ & 0.076 \\
\hline & & & $(0.050)$ & $(0.044)$ & $(0.385)$ \\
\hline \multirow[t]{2}{*}{ Unemployment rate, ‘06 } & & & -0.985 & -0.760 & -0.144 \\
\hline & & & $(1.798)$ & $(2.106)$ & (2.938) \\
\hline \multirow[t]{2}{*}{ Unemployment rate, ‘01 } & & & -1.523 & -2.007 & -4.407 \\
\hline & & & $(1.365)$ & (1.359) & $(3.122)$ \\
\hline \multirow[t]{2}{*}{ Default rate, '06 } & & & -2.661 & -2.877 & 3.918 \\
\hline & & & $(2.061)$ & $(2.223)$ & $(14.229)$ \\
\hline \multirow[t]{2}{*}{ Default rate, '01 } & & & -0.341 & -0.809 & -3.204 \\
\hline & & & $(1.891)$ & $(2.080)$ & $(6.192)$ \\
\hline \multirow[t]{2}{*}{$\begin{array}{l}\text { Fraction with credit score under } 660 \text {, } \\
\text { ' } 01\end{array}$} & & & $-1.523^{*}$ & $-1.263^{*}$ & -0.384 \\
\hline & & & $(0.597)$ & $(0.593)$ & $(1.675)$ \\
\hline \multirow[t]{2}{*}{ Credit card utilization rate, ‘06 } & & & $4.261^{* *}$ & $4.017 * *$ & 0.602 \\
\hline & & & $(0.793)$ & $(0.762)$ & (7.349) \\
\hline \multirow[t]{2}{*}{ Fraction black, ' 00} & & & 0.262 & 0.220 & 0.303 \\
\hline & & & $(0.226)$ & $(0.220)$ & $(0.490)$ \\
\hline \multirow[t]{2}{*}{ Fraction homeowner, ‘00 } & & & $0.466+$ & 0.394 & 0.267 \\
\hline & & & $(0.230)$ & $(0.249)$ & $(0.816)$ \\
\hline \multirow[t]{2}{*}{ Fraction with high school or less, ' 00} & & & -0.417 & -0.345 & -0.939 \\
\hline & & & $(0.309)$ & $(0.291)$ & $(1.065)$ \\
\hline \multirow[t]{2}{*}{ Ln (Median household income, ‘00) } & & & $-0.575^{* *}$ & $-0.460 * *$ & $-0.929 *$ \\
\hline & & & $(0.149)$ & $(0.141)$ & $(0.409)$ \\
\hline \multirow[t]{2}{*}{ Ln(Median home value, ’00) } & & & $0.251^{* *}$ & $0.199 * *$ & 0.615 \\
\hline & & & $(0.062)$ & $(0.072)$ & $(0.468)$ \\
\hline
\end{tabular}




Employment share in construction,
'06
Employment share in real estate, '06

$* *, *,+$ Coefficient estimate statistically distinct from 0 at the $1 \%, 5 \%$, and $10 \%$ levels, respectively. 
Table 4. Household Leverage Increase from 2002Q4 to 2006Q4 and Auto Sales Growth from 2006Q4 to 2009Q2

The regression in columns 2 through 5 are weighted by the number of households in the county as of 2000. Column 5 reports coefficients from the second stage of an IV specification where the change in the debt to income ratio from 2002 to 2006 is instrumented with housing supply inelasticity of the county as constructed by Saiz (2008). Standard errors are clustered by state.

Dependent variable: Auto sales growth, '06Q4 to '09Q2
(1)
(2)
(3)
(4)
(5)

\begin{tabular}{|c|c|c|c|c|c|}
\hline & Unweighted & Weighted & Weighted & Weighted & Weighted IV \\
\hline \multirow[t]{2}{*}{ Change in debt to income, ' 02 to ' 06} & $-0.222 * *$ & $-0.236 * *$ & $-0.116^{*}$ & $-0.122 *$ & -0.528 \\
\hline & $(0.035)$ & $(0.037)$ & $(0.048)$ & $(0.051)$ & $(0.326)$ \\
\hline \multirow[t]{2}{*}{ Debt to income, '01 } & & & $-0.250^{* *}$ & $-0.238 * *$ & -0.106 \\
\hline & & & $(0.049)$ & $(0.053)$ & $(0.120)$ \\
\hline \multirow[t]{2}{*}{ Unemployment rate, ‘06 } & & & -0.406 & -1.469 & 2.589 \\
\hline & & & $(2.364)$ & $(2.292)$ & (3.029) \\
\hline \multirow[t]{2}{*}{ Unemployment rate, ‘01 } & & & -2.089 & -2.009 & -3.748 \\
\hline & & & $(1.389)$ & $(1.373)$ & $(2.880)$ \\
\hline \multirow[t]{2}{*}{ Default rate, '06 } & & & -0.672 & 0.078 & 0.869 \\
\hline & & & $(2.399)$ & $(2.336)$ & $(3.031)$ \\
\hline \multirow[t]{2}{*}{ Default rate, ' 01} & & & 0.43 & 0.877 & -0.906 \\
\hline & & & $(2.199)$ & $(2.194)$ & $(5.112)$ \\
\hline \multirow[t]{2}{*}{$\begin{array}{l}\text { Fraction with credit score under } 660 \text {, } \\
\text { ‘ } 01\end{array}$} & & & $-1.699 * *$ & $-1.808 * *$ & -0.303 \\
\hline & & & $(0.556)$ & $(0.557)$ & $(1.614)$ \\
\hline \multirow[t]{2}{*}{ Credit card utilization rate, ‘06 } & & & $1.960 *$ & $1.806^{*}$ & -1.995 \\
\hline & & & $(0.809)$ & $(0.750)$ & $(3.906)$ \\
\hline \multirow[t]{2}{*}{ Fraction black, ‘ 00} & & & 0.126 & 0.119 & -0.174 \\
\hline & & & $(0.259)$ & $(0.259)$ & $(0.378)$ \\
\hline \multirow[t]{2}{*}{ Fraction homeowner, '00 } & & & -0.211 & $-0.422 *$ & -0.257 \\
\hline & & & $(0.204)$ & $(0.207)$ & $(0.468)$ \\
\hline \multirow[t]{2}{*}{ Fraction with high school or less, '00 } & & & 0.419 & 0.23 & -0.17 \\
\hline & & & $(0.424)$ & $(0.443)$ & $(0.834)$ \\
\hline \multirow[t]{2}{*}{ Ln (Median household income, '00) } & & & $-0.283+$ & -0.217 & -0.435 \\
\hline & & & $(0.160)$ & $(0.164)$ & $(0.319)$ \\
\hline \multirow[t]{2}{*}{ Ln(Median home value, ’00) } & & & $0.178+$ & $0.165^{+}$ & $0.485+$ \\
\hline & & & $(0.091)$ & $(0.093)$ & $(0.274)$ \\
\hline
\end{tabular}




\begin{tabular}{|c|c|c|c|c|c|}
\hline \multirow[t]{2}{*}{$\begin{array}{l}\text { Employment share in construction, } \\
\text { ' } 06\end{array}$} & & & & -0.237 & 0.427 \\
\hline & & & & $(0.665)$ & (1.013) \\
\hline \multirow[t]{2}{*}{ Employment share in real estate, '06 } & & & & -2.716 & -4.209 \\
\hline & & & & (2.163) & (3.497) \\
\hline \multirow[t]{2}{*}{ Employment share in finance, '06 } & & & & -0.584 & -0.738 \\
\hline & & & & $(0.559)$ & $(0.948)$ \\
\hline \multirow[t]{2}{*}{ Employment share in retail, '06 } & & & & 0.881 & 1.465 \\
\hline & & & & $(0.551)$ & (1.299) \\
\hline \multirow[t]{2}{*}{ Employment share in exports, ‘06 } & & & & 0.003 & 0.004 \\
\hline & & & & $(0.006)$ & $(0.011)$ \\
\hline \multirow[t]{2}{*}{ Constant } & $-0.151 * *$ & $-0.150 * *$ & 1.498 & 1.161 & 0.081 \\
\hline & $(0.038)$ & $(0.053)$ & (1.118) & (1.143) & $(2.386)$ \\
\hline Number of counties & 450 & 450 & 450 & 449 & 218 \\
\hline $\mathrm{R}^{2}$ & 0.19 & 0.19 & 0.44 & 0.45 & 0.25 \\
\hline
\end{tabular}

**,*,+ Coefficient estimate statistically distinct from 0 at the $1 \%, 5 \%$, and $10 \%$ levels, respectively. 
Table 5. Household Leverage Increase from 2002Q4 to 2006Q4 and New Housing Permit Growth

The regression in columns 2 through 5 are weighted by the number of households in the county as of 2000. Column 5 reports coefficients from the second stage of an IV specification where the change in the debt to income ratio from 2002 to 2006 is instrumented with housing supply inelasticity of the county as constructed by Saiz (2008). Standard errors are clustered by state.

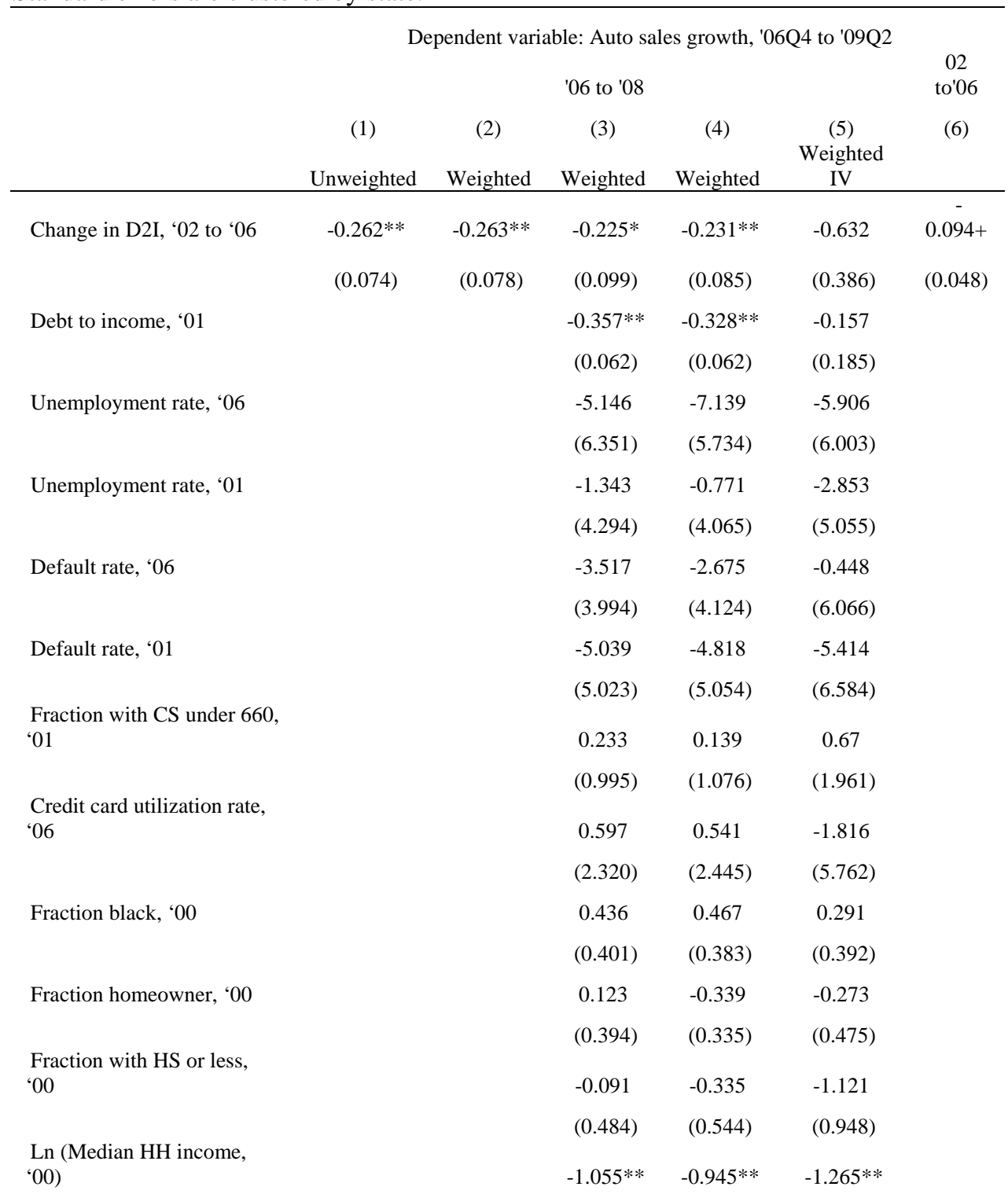




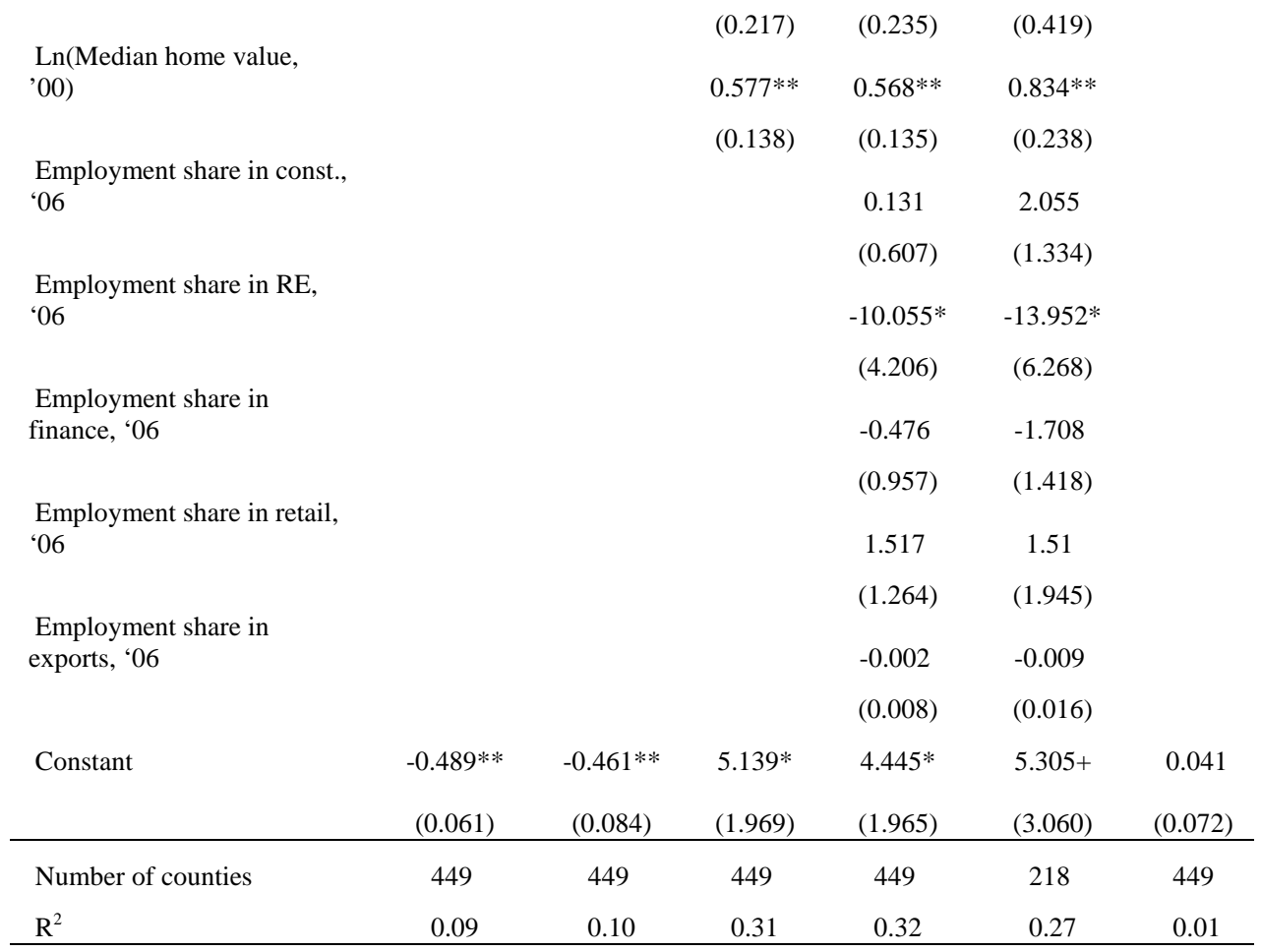

**,*,+ Coefficient estimate statistically distinct from 0 at the $1 \%, 5 \%$, and $10 \%$ levels, respectively. 
Table 6. Household Leverage Increase from 2002Q4 to 2006Q4 and Change in Unemployment Rate from 2006Q4 to 2009Q2

The regression in columns 2 through 5 are weighted by the number of households in the county as of 2000. Column 5 reports coefficients from the second stage of an IV specification where the change in the debt to income ratio from 2002 to 2006 is instrumented with housing supply inelasticity of the county as constructed by Saiz (2008). Standard errors are clustered by state.

(1)

(2)

(3)

(4)

(5)

\begin{tabular}{|c|c|c|c|c|c|}
\hline & $\begin{array}{l}\text { Un- } \\
\text { weighted }\end{array}$ & Weighted & Weighted & Weighted & $\begin{array}{c}\text { Weighted } \\
\text { IV }\end{array}$ \\
\hline \multirow[t]{2}{*}{ Change in debt to income, '02 to '06 } & $0.007 *$ & $0.011^{* *}$ & $0.008^{*}$ & $0.011 * *$ & $0.018^{*}$ \\
\hline & $(0.003)$ & $(0.003)$ & $(0.004)$ & $(0.003)$ & $(0.008)$ \\
\hline \multirow[t]{2}{*}{ Debt to income, '01 } & & & $0.012^{* *}$ & $0.013^{* *}$ & 0.005 \\
\hline & & & $(0.003)$ & $(0.003)$ & $(0.005)$ \\
\hline \multirow[t]{2}{*}{ Unemployment rate, ‘06 } & & & 0.205 & 0.157 & -0.257 \\
\hline & & & $(0.386)$ & $(0.377)$ & $(0.164)$ \\
\hline \multirow[t]{2}{*}{ Unemployment rate, '01 } & & & 0.321 & $0.347+$ & 0.093 \\
\hline & & & $(0.220)$ & $(0.200)$ & $(0.090)$ \\
\hline \multirow[t]{2}{*}{ Default rate, '06 } & & & 0.205 & 0.178 & 0.214 \\
\hline & & & $(0.206)$ & $(0.218)$ & $(0.185)$ \\
\hline \multirow[t]{2}{*}{ Default rate, '01 } & & & 0.116 & 0.124 & 0.015 \\
\hline & & & $(0.179)$ & $(0.178)$ & $(0.194)$ \\
\hline \multirow[t]{2}{*}{ Fraction with credit score under 660 , ' 01} & & & 0 & 0.018 & 0.035 \\
\hline & & & $(0.046)$ & $(0.042)$ & $(0.050)$ \\
\hline \multirow[t]{2}{*}{ Credit card utilization rate, '06 } & & & -0.09 & -0.102 & -0.112 \\
\hline & & & $(0.106)$ & $(0.110)$ & $(0.123)$ \\
\hline \multirow[t]{2}{*}{ Fraction black, '00 } & & & 0.023 & 0.017 & 0 \\
\hline & & & $(0.018)$ & $(0.018)$ & $(0.014)$ \\
\hline \multirow[t]{2}{*}{ Fraction homeowner, '00 } & & & -0.005 & 0.021 & -0.007 \\
\hline & & & $(0.025)$ & $(0.026)$ & $(0.018)$ \\
\hline \multirow[t]{2}{*}{ Fraction with high school or less, ' 00} & & & $0.064 * *$ & $0.073^{* *}$ & 0.028 \\
\hline & & & $(0.021)$ & $(0.021)$ & $(0.020)$ \\
\hline \multirow[t]{2}{*}{ Ln (Median household income, ‘00) } & & & 0.02 & 0.014 & 0.004 \\
\hline & & & $(0.014)$ & $(0.013)$ & $(0.011)$ \\
\hline Ln(Median home value, ’00) & & & -0.003 & -0.003 & -0.007 \\
\hline
\end{tabular}




\begin{tabular}{|c|c|c|c|c|c|}
\hline & & & $(0.011)$ & $(0.009)$ & $(0.008)$ \\
\hline \multirow[t]{2}{*}{ Employment share in construction, '06 } & & & & -0.065 & -0.075 \\
\hline & & & & $(0.044)$ & $(0.046)$ \\
\hline \multirow[t]{2}{*}{ Employment share in real estate, ' 06} & & & & 0.219 & 0.005 \\
\hline & & & & $(0.208)$ & $(0.155)$ \\
\hline \multirow[t]{2}{*}{ Employment share in finance, '06 } & & & & 0.014 & $0.056+$ \\
\hline & & & & $(0.046)$ & $(0.032)$ \\
\hline \multirow[t]{2}{*}{ Employment share in retail, '06 } & & & & $-0.133^{*}$ & -0.032 \\
\hline & & & & $(0.054)$ & $(0.037)$ \\
\hline \multirow[t]{2}{*}{ Employment share in exports, '06 } & & & & $0.001^{* *}$ & 0 \\
\hline & & & & $(0.000)$ & $(0.000)$ \\
\hline \multirow[t]{2}{*}{ Constant } & $0.048^{* *}$ & $0.047 * *$ & $-0.188+$ & -0.131 & 0.039 \\
\hline & $(0.003)$ & $(0.004)$ & $(0.111)$ & $(0.104)$ & $(0.091)$ \\
\hline Number of counties & 450 & 450 & 450 & 449 & 218 \\
\hline $\mathrm{R}^{2}$ & 0.04 & 0.10 & 0.30 & 0.34 & 0.44 \\
\hline
\end{tabular}

**,*,+ Coefficient estimate statistically distinct from 0 at the $1 \%, 5 \%$, and $10 \%$ levels, repectively. 
Table 7. Consumer Credit Constraints and the Deepening of the Recession from 2008Q3 to 2009Q2

This table presents coefficient estimates of the effect of credit card utilization rates on auto sales and unemployment. Column 3 (4) restricts the sample to firms in the bottom (top) decile counties of the change in debt to income from 2002 to 2006 distribution. The specification reported in column 3 includes the following control variables: the unemployment rate as of 2001Q4 and 2006Q4, the fraction of population that is black, the fraction of homeowners, the fraction with a high school education or less, and the fraction of employment in construction, real estate, finance, retail and export industries. All regressions are weighted by the number of households and standard errors are clustered by state.

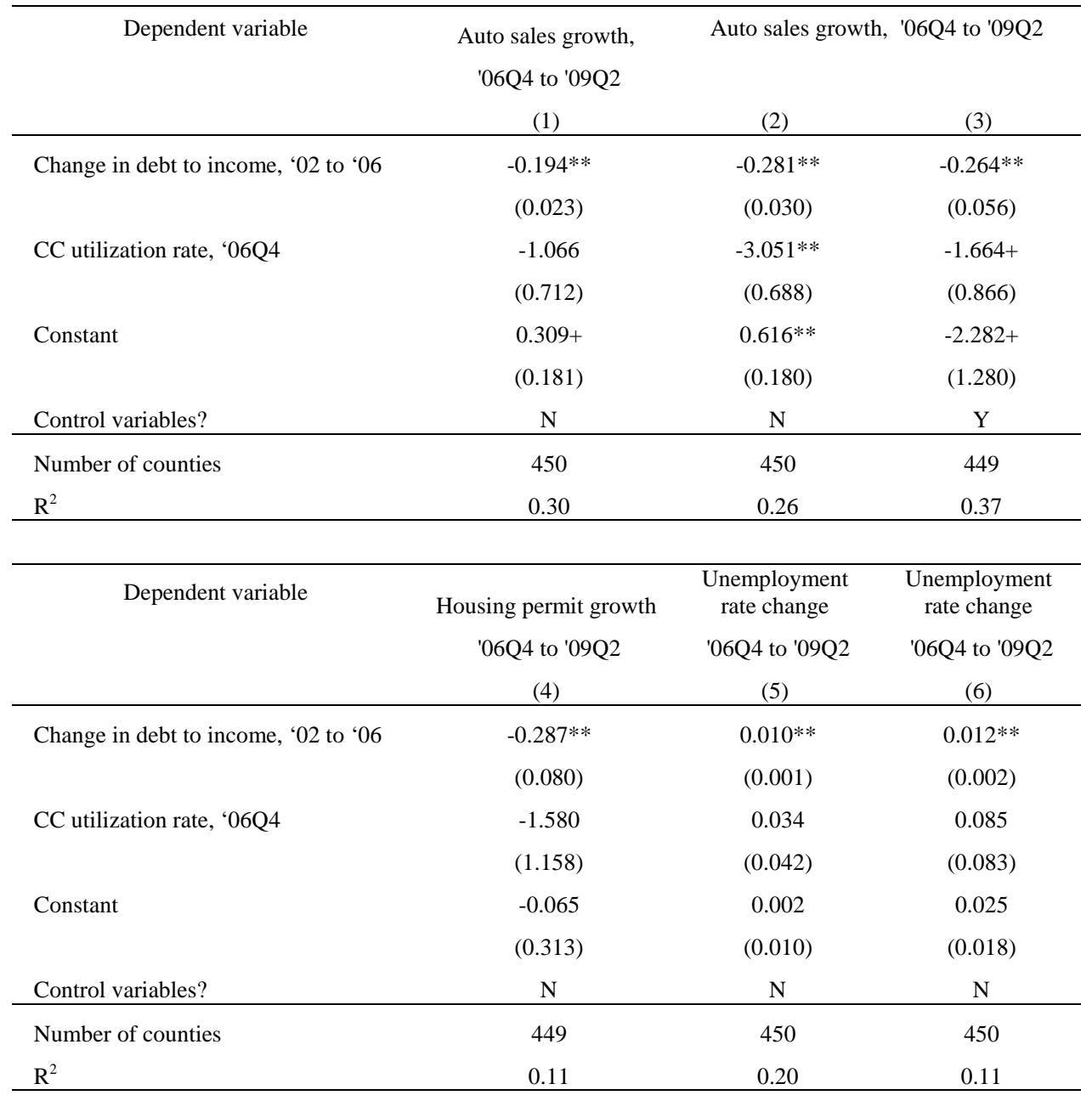

**,*,+ Coefficient estimate statistically distinct from 0 at the $1 \%, 5 \%$, and $10 \%$ levels, respectively 
Table 8. Can the Effect of Household Leverage on Recession Severity be Due to Local Banking Effects?

The coefficient estimates reported in columns 1 through 3 are from specifications that isolate the sample to counties where the banks have less than 10 percent of their deposits within the same county. Columns 4 through 6 report coefficient estimates from specifications that include measures of bank performance within the county. All specifications are weighted by the number of households in the county as of 2000 . Standard errors are clustered by state.

Only countries where banks have $<10 \%$ local deposits

(1)

(2)

Increase in

Dependent variable :

New Housing

Permit growth unemployment

Auto sales growth,

rate

\begin{tabular}{|c|c|c|c|}
\hline & '06q4 to '09q2 & '06 to '08 & '06q4 to '09q2 \\
\hline \multirow[t]{2}{*}{ Change in debt to income, '02 to '06 } & $-0.219 * *$ & $-0.170^{* *}$ & $0.007^{*}$ \\
\hline & $(0.035)$ & $(0.039)$ & $(0.003)$ \\
\hline \multirow[t]{2}{*}{ Constant } & $-0.172 *$ & $-0.558 * *$ & $0.053^{* *}$ \\
\hline & $(0.066)$ & $(0.073)$ & $(0.005)$ \\
\hline Number of counties & 52 & 51 & 52 \\
\hline $\mathrm{R}^{2}$ & 0.3 & 0.08 & 0.1 \\
\hline
\end{tabular}

Include controls for performance of banks in country

(4)

(5)

(6)

\begin{tabular}{|c|c|c|c|}
\hline Dependent variable : & $\begin{array}{c}\text { Auto sales growth, } \\
\text { '06q4 to '09q2 }\end{array}$ & $\begin{array}{l}\text { New Housing } \\
\text { Permit Growth } \\
\text { '06q4 to '09q2 }\end{array}$ & $\begin{array}{l}\text { Increase in } \\
\text { unemployment } \\
\text { rate } \\
\text { '06q4 to '09q2 }\end{array}$ \\
\hline \multirow[t]{2}{*}{ Change in debt to income, '02 to '06 } & $-0.236 * *$ & $-0.255^{* *}$ & $0.010^{* *}$ \\
\hline & $(0.036)$ & $(0.064)$ & $(0.002)$ \\
\hline \multirow[t]{2}{*}{$\begin{array}{l}\text { Change in charge-offs for banks in county, } \\
\text { '05 to '08 }\end{array}$} & -2.334 & 2.255 & -0.061 \\
\hline & $(2.464)$ & (3.998) & $(0.132)$ \\
\hline \multirow[t]{2}{*}{$\begin{array}{l}\text { Change in net income for banks in county, } \\
\text { '05 to '08 }\end{array}$} & $14.537^{*}$ & $25.300 * *$ & $-1.133^{* *}$ \\
\hline & $(5.609)$ & (8.999) & $(0.343)$ \\
\hline \multirow[t]{2}{*}{ Constant } & -0.014 & $-0.307^{* *}$ & $0.039 * *$ \\
\hline & $(0.062)$ & $(0.089)$ & $(0.004)$ \\
\hline Number of counties & 450 & 449 & 450 \\
\hline $\mathrm{R}^{2}$ & 0.25 & 0.16 & 0.18 \\
\hline
\end{tabular}

**,*,+ Coefficient estimate statistically distinct from 0 at the $1 \%, 5 \%$, and $10 \%$ levels, respectively. 


\section{Appendix Table. 20 percent of Counties in Sample, Ordered by Change in Debt to Income from 2002 to 2006 (Largest Increase First)}

This table lists every 5th county in our sample, ordered by the largest increase in the household debt to income ratio from 2002 to 2006. There are a total of 450 counties in our sample, and 90 counties in this list.

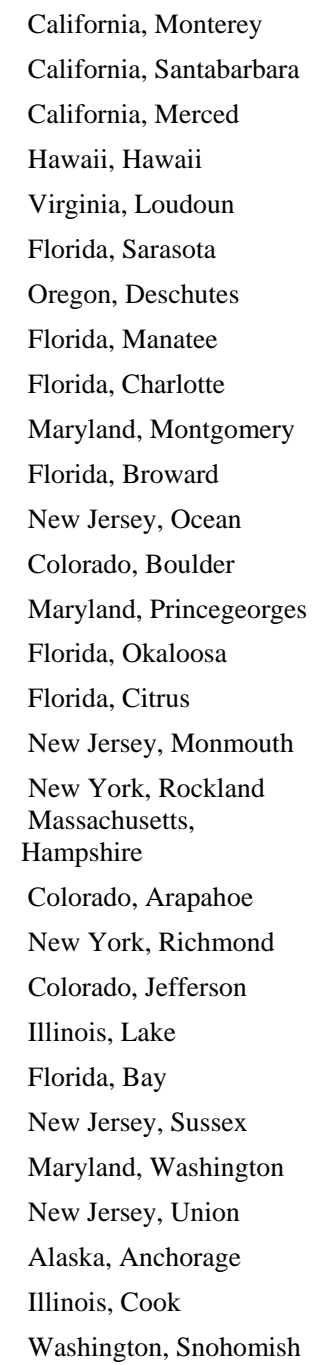

$$
32
$$

31

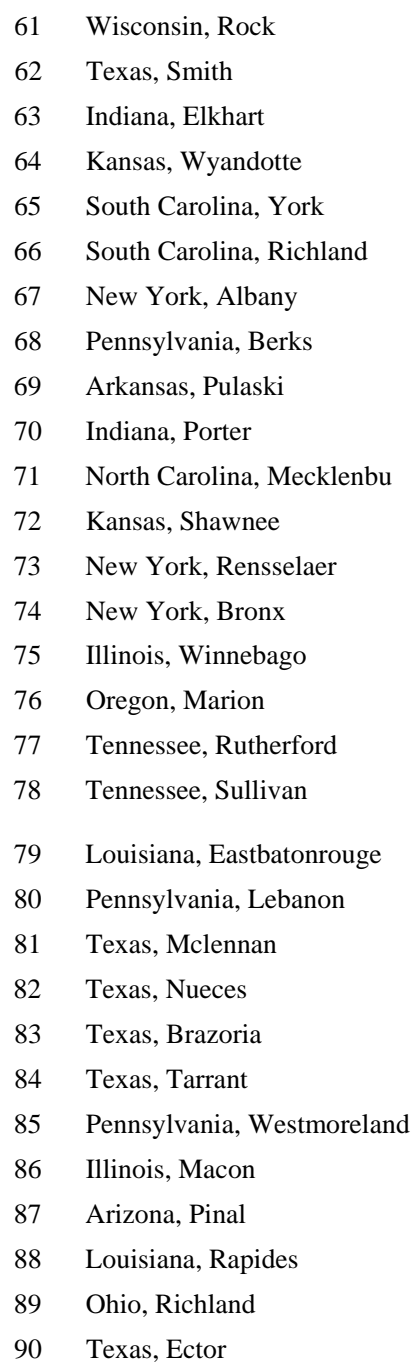

